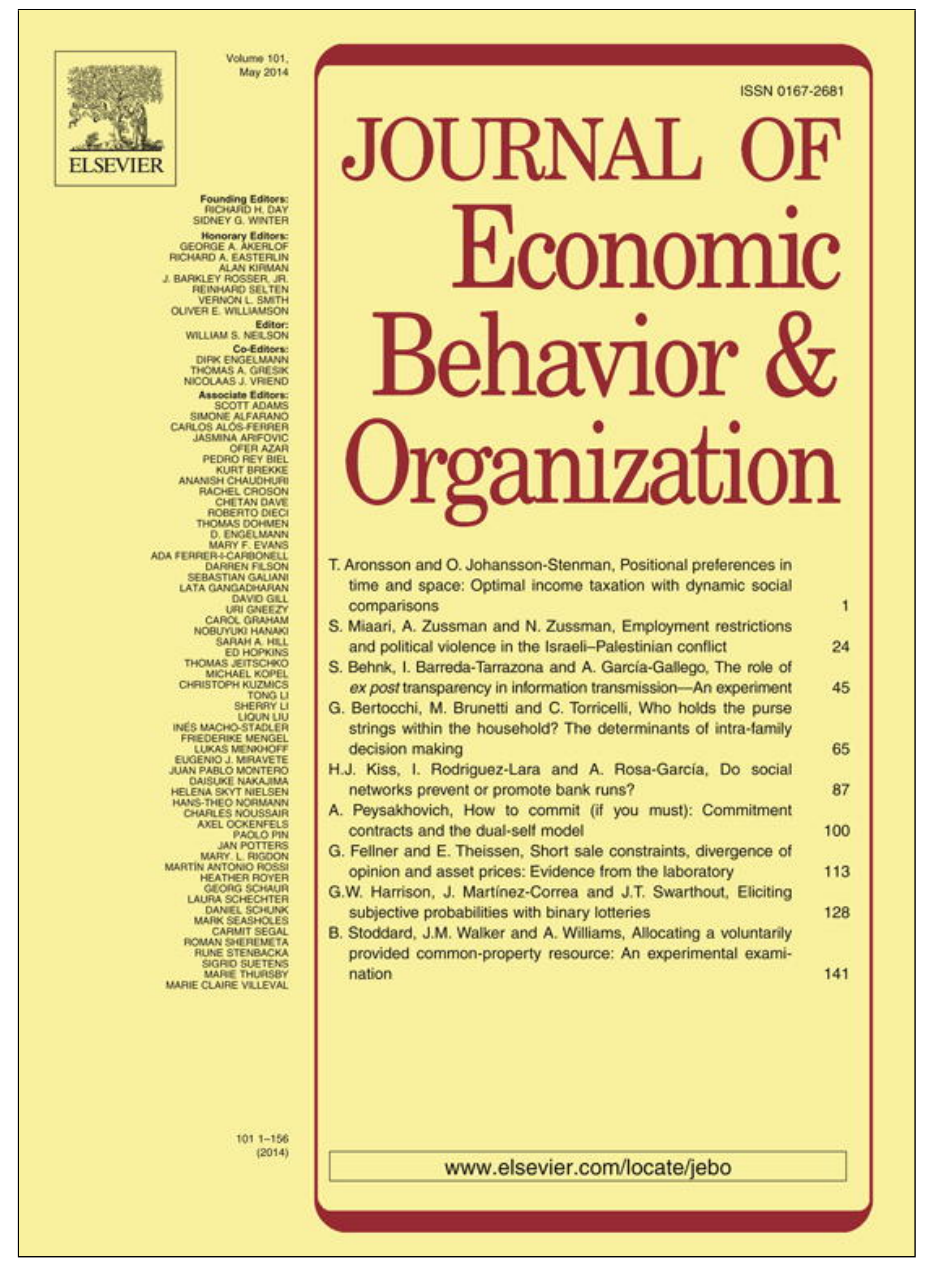

This article appeared in a journal published by Elsevier. The attached copy is furnished to the author for internal non-commercial research and education use, including for instruction at the authors institution and sharing with colleagues.

Other uses, including reproduction and distribution, or selling or licensing copies, or posting to personal, institutional or third party websites are prohibited.

In most cases authors are permitted to post their version of the article (e.g. in Word or Tex form) to their personal website or institutional repository. Authors requiring further information regarding Elsevier's archiving and manuscript policies are encouraged to visit: 


\title{
Who holds the purse strings within the household? The determinants of intra-family decision making ${ }^{\text {th }}$
}

\author{
Graziella Bertocchi ${ }^{\mathrm{a}, \mathrm{b}, \mathrm{c}, *}$, Marianna Brunetti ${ }^{\mathrm{d}, \mathrm{e}, \mathrm{f}}$, Costanza Torricelli $^{\mathrm{a}, \mathrm{f}}$ \\ a University of Modena and Reggio Emilia, Viale Berengario 51, 41121 Modena, Italy \\ b CEPR, United Kingdom \\ c IZA, Germany \\ d University of Rome Tor Vergata, Via Columbia 2, 00133 Roma, Italy \\ e CEIS, Italy \\ f CEFIN, Italy
}

\section{A R T I C L E I N F O}

\section{Article history:}

Received 13 February 2013

Received in revised form 4 February 2014

Accepted 14 February 2014

Available online 23 February 2014

\section{JEL classification:}

J12

D13

E21

G11

Keywords:

Family economics

Intra-household decision making

Gender differences

Financial choices

\begin{abstract}
A B S T R A C T
We study the determinants of intra-household decision-making responsibility over economic and financial choices using a direct measure provided in the 1989-2010 Bank of Italy Survey of Household Income and Wealth. We find that the probability that the wife is responsible for decisions increases as the wife's characteristics in terms of age, education and income become closer or even higher than those of her husband's. Thus, consistently with a bargaining approach, decision-making responsibility is associated with marriage heterogamy, and not only along strictly economic dimensions. However, in support of an alternative household production approach, we also find that the probability that the wife is responsible is lower when she is employed, which suggests the presence of a specialization pattern assigning responsibility to the spouse with more available time. Our results are robust to additional controls and alternative samples.
\end{abstract}

(c) 2014 Elsevier B.V. All rights reserved.

\section{Introduction}

The goal of this paper is to investigate the determinants of intra-household decision making with respect to economic and financial choices. Using a direct measure of actual decision-making responsibility, we study its main determinants taking into account individual characteristics of each spouse, household characteristics, and aggregate background factors. To identify the drivers of decision-making responsibility has crucial implications for understanding how resources are distributed within

\footnotetext{
is The authors would like to thank the Editor William Neilson, an Associate Editor and two referees, as well as seminar participants at Queen's University Belfast and at the CHILD-RECent Workshop on the Economics of the Family, Education and Social Capital in Modena, for valuable comments and suggestions. Generous financial support from Fondazione Cassa di Risparmio di Modena and the Italian University Ministry is gratefully acknowledged.

* Corresponding author at: University of Modena and Reggio Emilia, Viale Berengario 51, 41121 Modena, Italy. Tel.: +39 0592056856.

E-mail addresses: graziella.bertocchi@unimore.it (G. Bertocchi), marianna.brunetti@uniroma2.it (M. Brunetti), costanza.torricelli@unimore.it (C. Torricelli).
} 
the family, how household decisions are made in a variety of economic and non-economic realms, and how gender-based development initiatives should be designed.

Direct measures of decision responsibility are however very rare. Our measure is provided by a repeated cross-sectional survey conducted by the Bank of Italy - the Survey of Household Income and Wealth (SHIW) - that reports who, within the household, is declared as the head, i.e., the person who is responsible for financial and economic choices. Since the dataset now includes eleven waves, covering a 22 years period from 1989 to 2010, it represents a unique tool for the analysis of decision making, its evolution, and its determinants.

Previous theoretical research has developed models of household bargaining improving over the implications of a unitary approach to family economics. The assumption behind the bargaining approach is that individuals prefer to hold the purse strings and that they are more likely to be the household head the more resources they have. At the empirical level the search for the determinants of decision making has considered various factors such as each spouse's relative income, age, education, health, and also cultural factors involving race and religion. The main conclusion from the empirical literature we will review is that economic factors, captured mainly by differences in earnings but also in occupational status, are always decisive in determining which spouse is responsible for household decisions, while the evidence on the influence of other factors is more mixed.

The relative characteristics of the spouses are not the only determinants of decision making within the household. The division of labor among the partners and the associated specialization patterns within a household production framework have also been recognized as a decisive factor. However, according to this perspective a working wife is less likely to take decision responsibility than a wife that specializes in home production. Therefore, specialization carries implications which are opposite to those of the bargaining approach, since it implies that individuals may actually prefer to delegate decision-making responsibility to their spouses.

In this paper we aim at exploring the relative explanatory power of the bargaining and the specialization approach. Moreover, within the former, we investigate whether, beside strictly economic differentials, other sorts of marriage heterogamy such as age and education emerge as equally important determinants of decision responsibility.

We start by presenting the stylized facts. We show how our measure of female decision-making responsibility, which is captured by the proportion of households headed by the wife, has increased through time. We also illustrate the evolution of the factors that are more likely to be responsible for the observed changes in intra-household dynamics. For individual characteristics such as age, education, income, and occupational status, we document how intra-family gender differentials have changed. We also report trends for aggregate indicators such as female labor market participation, to account for the evolution of women's economic condition, and the incidence of divorce, to understand the evolution of family structure. Italy provides an ideal setting for our investigation. On the one hand, the sample period witnesses significant developments, along the gender dimension, in the economic and financial behavior of Italian households, with a substantial increase in the number of females declared as household heads. At the same time, the Italian society undergoes a number of important changes which may be linked with this phenomenon. For instance, we observe a pronounced transformation of the Italian family structure: while divorce became legal in Italy only in 1974, divorce figures boost in the most recent years of our sample. Moreover, women's participation in the labor market has been slowly increasing since the early post-war period. Even though it remains limited in an international comparison, its expansion is associated with a profound change in the role of women within family and society. The educational attainment of Italian women, particularly at the higher education level, is quickly catching up relative to that of men, a tendency which is common to other countries. Our dataset is rich enough to account for these developments.

Our next step is to study the empirical evolution of decision making by modeling the probability that the wife is in charge of economic and financial decisions as a function of individual characteristics of both spouses, household variables, and aggregate background factors. Among potential determinants of decision responsibility we are especially interested in within-couple differentials in terms of age, education and income, which should account for a bargaining-based explanation, and in the employment status of the female partner, which should reflect specialization patterns.

Firstly, our findings confirm that the probability that the wife is responsible for decisions increases as the wife's characteristics in terms of age, education and income become closer or even higher that the corresponding husband's ones. In other words, the decision-making process involving husband and wife is not just a question of money, but also of other not strictly economic individual characteristics, thus suggesting that factors such as knowledge, human capital accumulation, experience, seniority, and savviness can play an independent role. This pattern appears to be intensifying with time over our sample period.

Second, we also find that the probability that the wife is responsible is lower when she is employed, which suggests the presence of a division of tasks operating within the family, with more responsibility for the spouse who has more time to devote to decision making.

Finally, we show that decision responsibility is also associated with household characteristics such as household size and total income and wealth, while aggregate background factors do not add further explanatory power.

In a series of robustness checks we also show that our results hold even after controlling for the type of tasks households face, distinguished between simple and complex economic and financial decisions. Similarly, using finer definitions of occupational status carries additional explanatory power but does not alter our conclusion. For an alternative sample of non-married couples, we find somewhat different results which confirm the practical relevance of the institution of 
marriage. Finally for a sub-sample of middle-age (i.e., 51-61 year-old) couples we find that age no longer matters, in line with a stream of literature based on surveys exclusively administered to similar couples.

Our conclusion is that the allocation of decision-making responsibility responds both to a wide array of differentials that can be associated with the relative bargaining power of the partners and to the division of labor within the couple. In other words, control over purse strings matters but so does time availability. This conclusion suggests the presence of complex interactions documented by the data which cannot fully be accounted for by a single analytical framework, possibly because it is hard to draw a distinction between those aspects of household finances involving major strategic choices and those simply requiring routine day-to-day management.

Our results carry important implications also with respect to the literature that, in the absence of a direct measure of responsibility, tries to estimate its impact on a variety of decisions by using proxies often defined as dummy variables capturing the fact that the wife is older or more educated. We show that these proxies are poor predictors of actual decision responsibility, both because they measure intra-family differences in a coarser fashion, if compared to our differentials, and because they fail to account for the fact that decision responsibility is simultaneously determined by individual and household variables which are often omitted.

The rest of the paper is organized as follows. Section 2 summarizes the related literature. In Section 3 we introduce a simple conceptual framework to guide our empirical investigation. Section 4 describes our dataset and reports stylized facts. Section 5 presents our empirical findings and Section 6 performs robustness checks. Section 7 concludes and suggests directions for future research.

\section{Related literature}

The relevance of gender within the literature on household decisions is well established for a variety of economic and noneconomic issues, ranging from political choices (Edlund and Pande, 2002) and preferences toward the size of government (Lott and Kenny, 1999) to wealth accumulation and saving behavior (Zissimopoulos et al., 2013). Examples within the literature on financial decisions and risk preferences are Jianakoplos and Bernasek (1998), Sundén and Surette (1998), Barber and Odean (2001), Lusardi and Mitchell (2008), Croson and Gneezy (2009), Dohmen et al. (2011), and Halko et al. (2012). The prevailing conclusion from these studies is that women reveal a higher degree of risk aversion, so that households where decisions are made by women tend to select less risky investments. For Italian SHIW data, these results are confirmed by Guiso and Jappelli (2002) and Bertocchi et al. (2011).

A deeper question behind these results is what determines which spouse is in control of family decisions. There is a relatively small empirical literature on the determinants of the intra-household decision-making process that focuses, as we do, on direct measures of the allocation of responsibilities over a number of decisions. One reason why the literature is small is that such measures are rare.

A number of papers are based on data collected by the US Health and Retirement Study (HRS), which is one of the few surveys that provide specific information about this issue. In particular, couples are asked to report which spouse has the "final say" in making major economic and financial decisions for the household. The question was asked in the first two waves, i.e., 1992 and 1994, with comparable answers. Subsequently, it was only asked of the much smaller sample of new entrants. Therefore, most studies only use the first wave. Since the HRS is sponsored by the National Institute on Aging, the survey initially included only individuals between the age of 51 and 61 in 1991, plus their partners (who may have been older or younger). Therefore, the sample reflects a narrow share of the population. Another distinctive feature of the HRS survey is that the same question is answered independently by both the husband and the wife, so that they may well disagree on the answer. It turns out that indeed in the first wave only $63.5 \%$ of the partners agreed. Based on the 1992 wave, Elder and Rudolph (2003) find that decisions are more likely to be made by the spouse with more financial knowledge, more education, and a higher wage, irrespective of gender. They interpret this evidence as supportive of a bargaining approach to decision making, rather than a unitary approach. The conclusions they reach hold true both for the husbands' and the wives' opinions and over both the entire sample and the sub-sample consisting of those households where the partners agree. Based on the same data, Friedberg and Webb (2006) find that decision-making responsibility depends on relative earnings, even though the magnitudes of the estimated effects are moderate.

Lührmann and Maurer (2007) use data from the 2003 wave of the Mexican Health and Aging Study (MHS). The survey is similar in design to the US HRS and covers the Mexican population over 50 years of age (and their partners). They find that for this sample education and employment status are associated with more individual responsibility for decisions, especially for women. Health, income, and the level of urbanity of the area in which the household lives also matter.

The UK Household Panel Survey also contains a 'final say' question and in addition it collects information about the allocation of different kinds of financial management decisions. Based on this additional information, Dobbelsteen and Kooreman (1997) are able to compare the predictions from the bargaining vs. the household production model, an aspect neglected in the previously reported contributions. They show that the latter carries limited explanatory power, since it only matters for everyday household spending, while a bargaining interpretation prevails for all other aspects ranging from big financial decisions to regular household bills.

Finally, this specific literature line includes Woolley (2003), who focuses on a small sample of 300 Canadians interviewed in 1995 about a number of specific financial tasks (cash withdrawals, writing checks, etc.). She finds that, consistently with a bargaining approach, males with higher income exert more control over decisions and that age also matters in the sense 
that younger women have more control but only on cash withdrawals. She also evaluates the relevance of the specialization approach by controlling for the employment status of the female partner. The fact that this variable is never significant questions its validity.

Summing up the literature which is closer to the present study, across the contributions reported above income emerges as the most robust determinant of intra-household decision-making responsibility, in a bargaining perspective. There is also some evidence that education and age may matter as well. The evidence supporting the household production model is instead rather weak.

A parallel research line has tried to estimate the consequences of bargaining within the family on a variety of economic and non-economic decisions. In the absence of direct measures, this literature typically relies on the use of proxies, often constructed as dummies measuring various dimensions of heterogamy, such as income, education, age, but also race and religion. For instance, Lundberg et al. (2003) focus on dummies for age differences to explain the decline in household consumption after retirement. Grossbard-Shechtman and Neuman (1988) analyze the link between age differential (measured not as a dummy but in actual number of years of difference) and women's labor force participation, with a negative effect on the latter being associated with older husbands. Lundberg and Ward-Batts (2000) show that a larger gap in the educational level, with the husband having more years of education than the wife, is associated with lower household wealth. Thomas (1994) finds that a dummy identifying wives that are more educated than their husbands is indicative of control over the allocation of household resources in Ghana. For China, Li and Wu (2010) propose a measure of women's relative power based on the gender of the first-born, with sons being associated with more power than daughters. Similarly, research on the determinants of marital instability shows the importance of socio-demographic disparity within the couple as a factor determining marital dissolution. Heaton (2002) and Teachman (2002) find that couples are more likely to divorce when they do not share the same education background, particularly when it is the wife who is more educated, and that this effect is stable, or even increasing, over time. Age difference is found to be associated with divorce by Pericoli and Ventura (2012), with the probability of divorce showing a positive dependence upon the squared age difference between husband and wife. Within an empirical investigation of households' investment decisions, Bertocchi et al. (2011) employ dummy variables capturing the fact that the wife is more educated, older, or earning more as proxies for marital instability.

Another stream of empirical research which is relevant for our perspective is the one that has documented and analyzed the patterns of assortative mating (see Lam, 1988; Kalmijn, 1991; Mare, 1991; Lewis and Oppenheimer, 2000) and how they are interrelated with husbands' and wives' educational and occupational achievements, as well as their change. While a general finding in this literature is the existence of positive assortative mating, trends in marital homogamy actually differ across traits, which underscores the importance of considering multiple dimensions of within-couple differentials.

\section{A conceptual framework}

A number of conceptual frameworks can help us account for the determinants of decision-making by couples, starting from early contributions by Becker's (1973) on the marriage market model and from bargaining theories developed, among others, by McElroy and Horney (1981). More recently, Apps and Rees (1988) and Chiappori (1988) have introduced the collective model of household behavior.

Our discussion will focus on two approaches: the bargaining approach and the household production approach.

As summarized by Browning et al. (2007), the bargaining approach can be outlined as follows. The household utility function can be expressed as a weighted sum of the individual utility functions of the partners, given by $U_{\text {household }}=\mu(\mathbf{z})$ $U_{\text {female }}+(1-\mu(\mathbf{z})) U_{\text {male }}$, where $\mu(\mathbf{z})$, defined on the $[0,1]$ interval, is the weight of the female partner, which carries a natural interpretation in terms of relative decision power. Clearly, if it is equal to 1 she would be exclusively in charge of decisions. Weights can be influenced by a number of factors given by the vector $\mathbf{z}$. In principle, a large number of variables may enter $\mathbf{z}$, including individual characteristics of the spouses as well as background variables affecting family structure and society in general. The above equation is also consistent with Becker (1973)'s view on the division of output within a couple, as well as with the idea that partners bargain over economic and financial control. The assumption behind this approach to the description of power distribution inside the household is that individuals prefer to hold the purse strings and that they are more likely to be the head the more resources they have, whereas individual resources can be interpreted not only in terms of income but also experience and education. Indeed the small literature previously reviewed in Section 2 (including Dobbelsteen and Kooreman, 1997; Elder and Rudolph, 2003; Woolley, 2003; Friedberg and Webb, 2006; Lührmann and Maurer, 2007) has explored factors reflecting income, employment status, age, education, financial knowledge, and health, as potential determinants of the weights.

However, decision responsibility for finances is a function not only of the resources that each individual owns, but also of the division of labor among the two partners. In other words, the allocation of decision-making responsibility also depends on the specialization pattern prevailing within the family. We are referring here to the household production model based on Becker's (1965) theory of the allocation of time. Under conditions that are often verified empirically, the wife would not

1 See Fernandez et al. (2005) for a model of sorting and Iyigun and Walsh (2007) for a model with spousal assortative matching. 
enter the labor market and would instead specialize in home production. Under this common specialization pattern, she would have more time at her disposal and she would therefore find herself in a better position to take responsibility for time-consuming tasks. The literature on household decision making has paid less attention to specialization as a potential explanation (notable exceptions are represented by Dobbelsteen and Kooreman, 1997; Woolley, 2003; Amuedo-Dorantes et al., 2010). However, it carries implications which are opposite to those of the bargaining approach, since it implies that individuals may actually prefer to delegate decision-making responsibility to their spouses because their own time is too valuable. Therefore, the underlying assumption now is that individuals no not aspire to hold the purse strings, the exact opposite of what lies behind the bargaining approach.

To sum up, the bargaining approach and the specialization framework offer different interpretations of what it means that the woman is responsible for economic and financial decisions. According to the former it reflects her relative power, while the latter implies that she simply has to deal with time-consuming chores. Empirically, each hypothesis leads to specific predictions and testable implications. If responsibility over economic and financial decisions is assigned through bargaining, we should expect the probability that the woman is responsible to increase with measures of her relative power, along several potential dimensions such as income, age and education. On the other hand, we can capture the explanatory power of the household production model through measures of the degree of specialization captured by employment status, with a higher probability that the woman is responsible in more specialized families. Alternatively, we can also test the specialization model by distinguishing between different degrees of complexity of economic and financial decisions.

\section{Data and stylized facts}

Our dataset spans over the 1989-2010 period and draws from the Bank of Italy Survey on Household Income and Wealth (SHIW) and from Istat (the Italian National Institute of Statistics). The SHIW is a repeated, biennial cross-sectional survey which provides over that period eleven waves $\left(1989,1991,1993,1995,1998,2000,2002,2004,2006,2008\right.$ and 2010). ${ }^{2}$ In each wave, data are collected for around 8000 households, out of which we select those where a married couple is present, for a total of 59,389 observations. ${ }^{3}$

The SHIW basic sample unit is the household defined as "a group of cohabiting people who, regardless for their relationships, satisfy their needs by pooling all or part of their incomes". In contrast with household surveys conducted in other countries, where the household head is defined on the basis of different attributes (e.g., highest income, or male gender), a distinctive feature of the Italian survey is to introduce the "declared" definition: accordingly, a household head is identified as the person who is responsible for the financial and economic choices of the household. ${ }^{4}$ This definition can be interpreted as an objective, joint evaluation of the balance within the decision-making process, or else as the outcome of the process of convergence of any potential initial disagreement. Therefore, the survey provides a direct and unambiguous measure of responsibility for economic and financial decisions. This is the proxy that we employ in this paper to capture the determinants of the allocation of decision power. ${ }^{5}$

With respect to the datasets used in previous contributions on intra-household decision making reviewed in Section 2, the SHIW measure presents several advantages. First of all, it is available for households of all ages. Second, information is provided for eleven waves, covering the 1989-2010 period. Third, the way the survey is administered does not give partners the option to disagree, since they can only report a joint single answer when asked to indicate the economic and financial head. This is why the measure is an effective proxy for the final outcome of any potential process of convergence of initial disagreement. Finally, our dataset provides information both on direct measures of decision-making responsibilities and on their potential determinants, including detailed individual characteristics of both spouses, household characteristics, and aggregate background variables.

The SHIW indeed provides plenty of demographic information on the household as a whole and on each household member. As for the former, we use household size, household income, and household net wealth (the latter including real and financial assets net of financial liabilities). For each partner, we consider age, education, occupational status, and disposable individual income. ${ }^{6}$ Since the 2000 wave, the SHIW provides additional information on the occupational status (i.e., having a tenure contract or a part-time job) and on the type of banking services used by the household (ranging from paying bills to financial assets trading), which we also include.

We supplement our dataset with aggregate variables based on data provided by Istat. ${ }^{7}$ These variables are the divorce hazard and the female employment rate, both at the regional level. ${ }^{8}$ The divorce hazard is the ratio of the number of divorces

\footnotetext{
2 Data are downloadable from http://www.bancaditalia.it/statistiche/indcamp/bilfait. More details on the SHIW are reported in the Appendix.

3 In Section 6.3 we also introduce an alternative sample of non-married couples, including 808 observations.

4 To be more precise, at the beginning of the in-person interview, the interviewer asks to list all household members beginning with the head of household,

i.e., the person primarily and effectively responsible for the household budget.

${ }^{5}$ Using the same dataset, Bertocchi et al. (2011) show that households headed by females choose less risky portfolios than those headed by males, which suggests that indeed our measure is economically relevant.

6 All monetary amounts are expressed in real terms using the 1989 Consumer Price Index provided by Istat.

7 Data are downloadable from http://www.istat.it

8 Italy is divided into 20 administrative units denominated regions, each consisting of several municipalities.
} 
Table 1

Descriptive statistics (pooled sample).

\begin{tabular}{|c|c|c|c|c|}
\hline Variables & Mean & St. dev. & Min & Max \\
\hline Female head & 0.1423 & 0.3494 & 0 & 1 \\
\hline $\begin{array}{l}\text { Household characteristics } \\
\text { Household size } \\
\text { Income } \\
\text { Wealth } \\
\text { Only wife works } \\
\text { Only husband works } \\
\text { None works } \\
\text { Simple tasks }\end{array}$ & $\begin{array}{r}3.2636 \\
20.1018 \\
133.0929 \\
0.0444 \\
0.3150 \\
0.3324 \\
0.7865\end{array}$ & $\begin{array}{r}1.1006 \\
15.1416 \\
247.2230 \\
0.2061 \\
0.4645 \\
0.4711 \\
0.4098\end{array}$ & $\begin{array}{c}2 \\
-27.5 \\
-445.0 \\
0 \\
0 \\
0 \\
0\end{array}$ & $\begin{array}{l}12 \\
614.4 \\
15,743.7 \\
1 \\
1 \\
1 \\
1\end{array}$ \\
\hline $\begin{array}{l}\text { Wife's characteristics } \\
\text { Age } \\
\text { Education } \\
\text { Income } \\
\text { Working } \\
\text { Employee } \\
\text { Self-employed } \\
\text { Tenured } \\
\text { Part-time } \\
\text { Housewife } \\
\text { Retired }\end{array}$ & $\begin{array}{r}49.4754 \\
2.9900 \\
4.3581 \\
0.3526 \\
0.2666 \\
0.0860 \\
0.3898 \\
0.0126 \\
0.4200 \\
0.2000\end{array}$ & $\begin{array}{r}14.1399 \\
1.0559 \\
5.6219 \\
0.4778 \\
0.4422 \\
0.2804 \\
0.4877 \\
0.1116 \\
0.4936 \\
0.4000\end{array}$ & $\begin{array}{c}16 \\
1 \\
-11.1 \\
0 \\
0 \\
0 \\
0 \\
0 \\
0 \\
0\end{array}$ & $\begin{array}{l}96 \\
6 \\
165.4 \\
1 \\
1 \\
1 \\
1 \\
1 \\
1 \\
1\end{array}$ \\
\hline $\begin{array}{l}\text { Husband's characteristics } \\
\text { Age } \\
\text { Education } \\
\text { Income } \\
\text { Working } \\
\text { Employee } \\
\text { Self-employed } \\
\text { Tenured } \\
\text { Part-time } \\
\text { Retired }\end{array}$ & $\begin{array}{r}53.1335 \\
3.0832 \\
13.7369 \\
0.6232 \\
0.4273 \\
0.1959 \\
0.2522 \\
0.0698 \\
0.3451\end{array}$ & $\begin{array}{r}14.3895 \\
1.0364 \\
12.0236 \\
0.4846 \\
0.4947 \\
0.3969 \\
0.4343 \\
0.2548 \\
0.4754\end{array}$ & $\begin{array}{c}19 \\
1 \\
-67.3 \\
0 \\
0 \\
0 \\
0 \\
\\
0\end{array}$ & $\begin{array}{l}98 \\
6 \\
607.0 \\
1 \\
1 \\
1 \\
1 \\
1\end{array}$ \\
\hline $\begin{array}{l}\text { Within-couples differentials } \\
\text { Age differential (wife-husband) } \\
\text { Education differential (wife-husband) } \\
\text { Income differential (wife-husband) }\end{array}$ & $\begin{array}{l}-3.6581 \\
-0.0932 \\
-9.3789\end{array}$ & $\begin{array}{r}4.0816 \\
0.7701 \\
12.2156\end{array}$ & $\begin{array}{c}-57 \\
-4 \\
-599.7\end{array}$ & $\begin{array}{l}48 \\
3 \\
100.9\end{array}$ \\
\hline $\begin{array}{l}\text { Dummies for within-couples differences } \\
\text { Wife older } \\
\text { Wife more educated } \\
\text { Wife earns more }\end{array}$ & $\begin{array}{l}0.1099 \\
0.1755 \\
0.0928\end{array}$ & $\begin{array}{l}0.3127 \\
0.3804 \\
0.2901\end{array}$ & $\begin{array}{l}0 \\
0 \\
0\end{array}$ & $\begin{array}{l}1 \\
1 \\
1\end{array}$ \\
\hline $\begin{array}{l}\text { Background variables } \\
\text { Divorce hazard } \\
\text { Female employment rate }\end{array}$ & $\begin{array}{l}0.1540 \\
0.3090\end{array}$ & $\begin{array}{l}0.0907 \\
0.0850\end{array}$ & $\begin{array}{l}0.0186 \\
0.1309\end{array}$ & $\begin{array}{l}0.4537 \\
0.4549\end{array}$ \\
\hline
\end{tabular}

Note: Statistics computed using sampling weights (pesofl2).

over the number of marriages. ${ }^{9}$ The female employment rate is the ratio between women employed over the total female working-age population.

Table 1 reports summary statistics for all the variables used in our pooled sample of married couples. Table A1 in the Appendix defines all the relevant variables. Only $14.23 \%$ of the couples report the wife as the household head. ${ }^{10}$ The average age is 53.13 for husbands, 49.48 for wives. Their education level is relatively close, at 3.08 and 2.99 respectively corresponding approximately to a secondary school degree, with a slightly larger standard variation for women. We find a marked difference in average individual income with husbands at around 13.73 thousands Euros and wives at around 4.36. This difference is reflected in the proportion of husbands and wives that work (62.32\% and $35.26 \%$, respectively). Table 1 also reports information about differences within the couples in all the above dimensions, as well as a set of dummies recording the fact that the wife is older, more educated and earning more, respectively. The latter confirm that wives are older than their husbands only in $11 \%$ of the cases, while they earn more in $9 \%$ of the cases despite being more educated in $18 \%$ of the cases.

\footnotetext{
${ }^{9}$ We employ the divorce hazard since, contrary to the crude divorce rate (divorces over every 1000 residents), it takes into account both the increasing dynamics of divorce and the decreasing dynamics of marriage.

10 While it is true that some misreporting may be present, if anything we would expect under-reporting, rather than over-reporting, of the fraction of women that are declared as household head. This is because of a cultural attitude that, as documented for example by Alesina and Giuliano (2010), leads to a relatively submissive role for Italian women.
} 


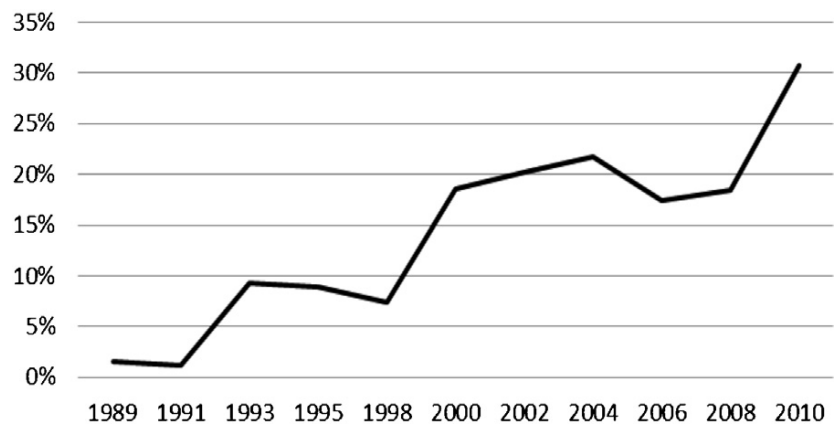

Fig. 1. Female head proportion. Note: Authors' elaborations on SHIW data.

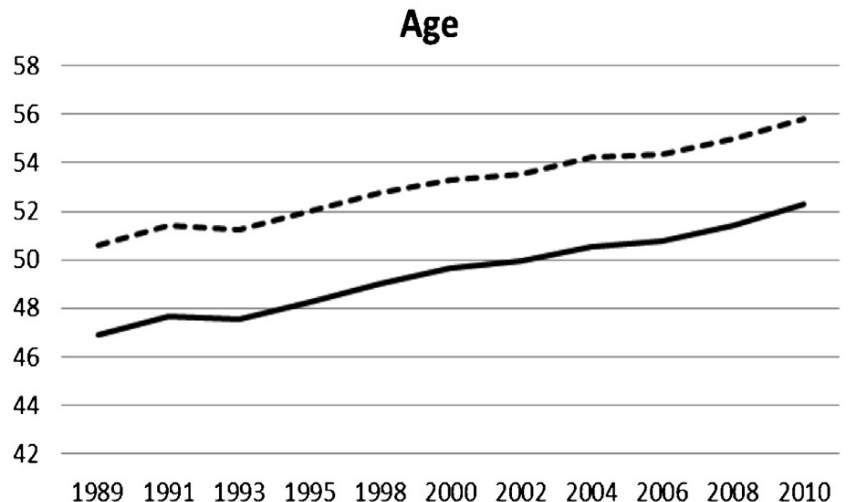

Income

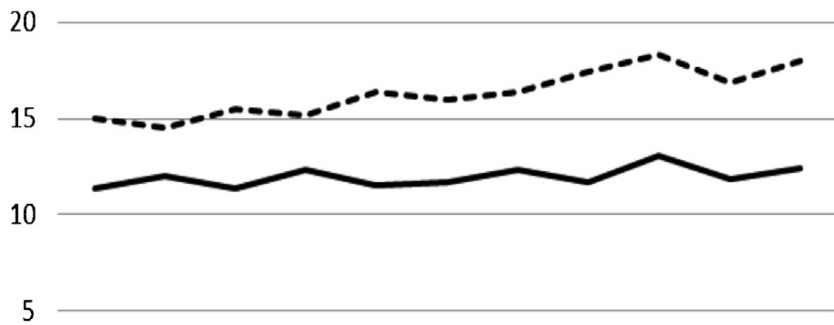

0

19891991199319951998200020022004200620082010

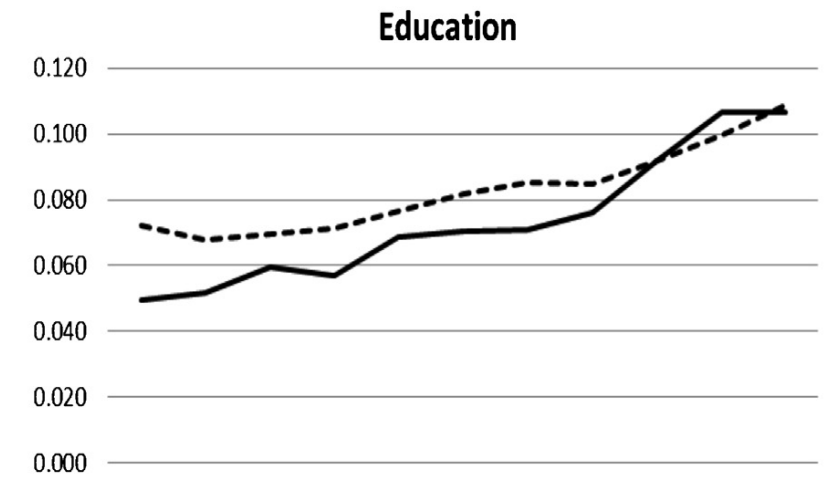

19891991199319951998200020022004200620082010

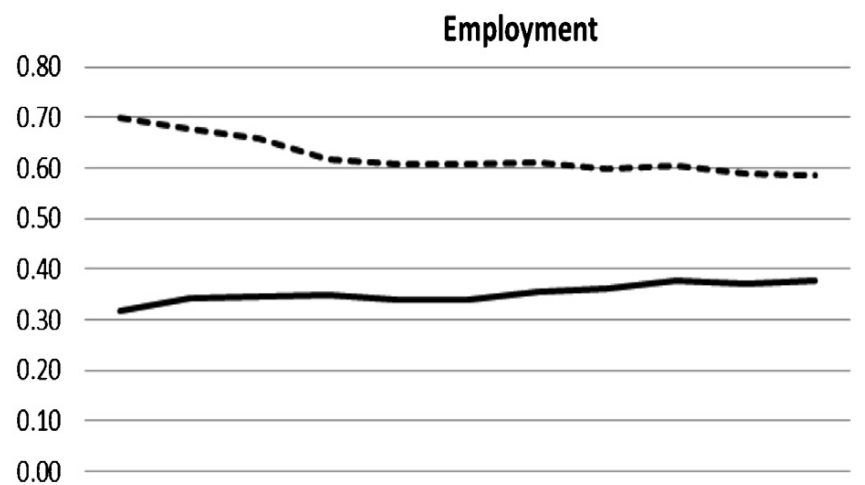

19891991199319951998200020022004200620082010

Fig. 2. Husbands' and wives' age, education, income and employment. Note: Authors' elaborations on SHIW data.

While Table 1 reports descriptive statistics for the pooled sample, Table A2 in the Appendix reports the same for the initial and final years of the sample, as well as the significance of a mean equality test. The time evolution of the main variables can also be illustrated graphically. Fig. 1 shows that the proportion of households reporting the wife as the economic decision maker has greatly increased from $1.6 \%$ in 1989 to $30.8 \%$ in 2010. Fig. 2 reports the evolution of age, education, income and employment for the wives and husbands in our sample. The upper-left panel shows that the average age of both partners has increased, reflecting both the general ageing in the population and the decline of marriage (the latter force tends to exclude younger generations from our sample of married couples). The average age difference has narrowed from 3.69 to 3.55 years. The average level of education has increased and the differential between genders has nearly disappeared as of 2010 (upper-right panel). Both trends point to increasing assortative mating patterns. The income differential (conditional on being working) has instead remained more stable (lower-left panel). The proportion of working husbands declines while the corresponding figures for women increases, providing evidence of convergence but also at the same time of persistence of a marked gender difference (lower-right panel).

Fig. 3 presents the evolution of two aggregate indicators, the divorce hazard and the female employment rate, measured at the regional level. The former jumps from $9.62 \%$ to $26.92 \%$ over the period under consideration (top panel). While the decline of marriage and the increasing diffusion of divorce represent a common tendency in industrialized countries, 

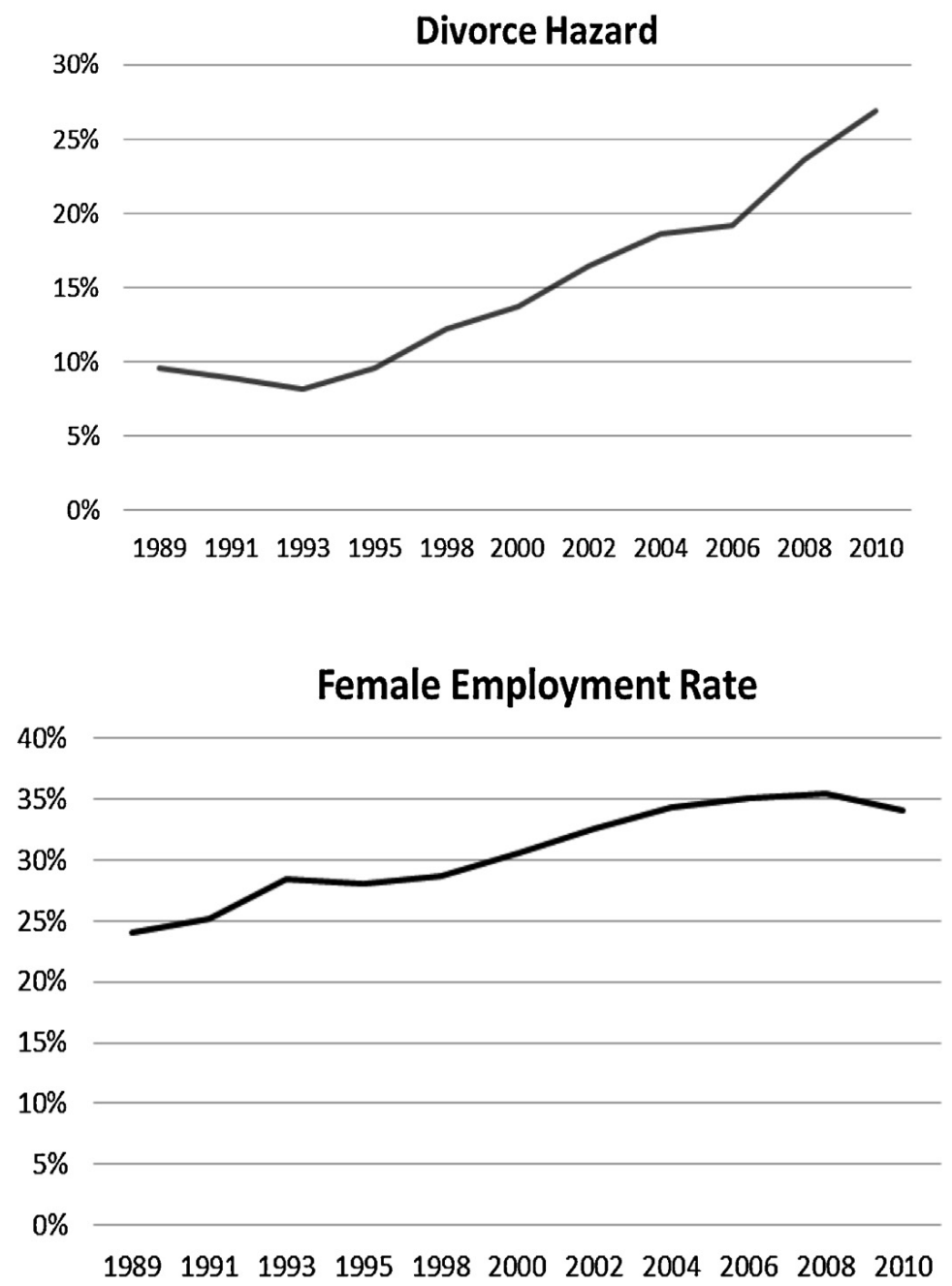

Fig. 3. Divorce hazard and female employment rate. Note: Authors' elaborations on Istat data. The graph at the top reports divorce hazard $\times 100$.

in this dimension the Italian society has experienced a particularly fast evolution. ${ }^{11}$ Female employment (bottom panel) increases from $24.05 \%$ to $34.11 \%$, even though women's labor market participation has historically been lower than in most industrialized countries. $^{12}$

Overall, these figures document a marked evolution of Italian economy and society, with a profound transformation of family structure and an increasing participation of women into the labor market, factors that can potentially affect decision making within households.

\section{Results}

Our empirical investigation consists in estimating a probit model for the probability that the wife is the household head, i.e., the primary economic and financial decision maker as declared by the couple. With respect to the conceptual framework presented in Section 3, we can only test whether $\mu(\mathbf{z})=0$ or $\mu(\mathbf{z})=1$. For this model, we run a set of pooled regressions with robust standard errors clustered at the regional level. All regressions include a set of time and regional dummies, with the initial year and Piedmont taken as reference categories. All tables report marginal effects. All variables used in the regressions are defined in Table A1 in the Appendix.

We start in Table 2 by inserting the individual characteristics of the wife and the husband separately. Next, in Table 3, we will exploit the same information in the form of differentials.

Table 2 presents as a benchmark a basic specification including four sets of variables (Column 1). The first set consists of standard household characteristics, namely the household size and its squared term as well as household income and

\footnotetext{
11 The slight initial decline is explained by a 1987 reform that reduced from five to three years the waiting time to file for divorce after a legal separation. This provoked a sudden jump of the divorce hazard, partially reversed in the early 1990s.

12 See Del Boca and Pasqua (2003) on the employment patterns of husbands and wives in Italy and Fernandez and Fogli (2009) for an international comparison of female labor force participation rates and for their link with a country's culture.
} 
Table 2

The determinants of decision-making responsibility.

\begin{tabular}{|c|c|c|}
\hline \multirow[t]{2}{*}{ Variables } & \multicolumn{2}{|c|}{ Dependent variable: female head } \\
\hline & $(1)$ & $(2)$ \\
\hline \multicolumn{3}{|l|}{ Household characteristics } \\
\hline Household size & $\begin{array}{l}0.0183^{* * *} \\
(2.917)\end{array}$ & $\begin{array}{l}0.0224^{* * *} \\
(3.444)\end{array}$ \\
\hline Household size ${ }^{2}$ & $\begin{array}{l}-0.0017^{* *} \\
(2.257)\end{array}$ & $\begin{array}{l}-0.0020^{* * *} \\
(2.676)\end{array}$ \\
\hline Income 2nd quartile & $\begin{array}{l}0.0172^{* *} \\
(2.496)\end{array}$ & $\begin{array}{l}0.0043 \\
(1.006)\end{array}$ \\
\hline Income 3rd quartile & $\begin{array}{l}0.0116 \\
(1.252)\end{array}$ & $\begin{array}{l}-0.0137^{* * *} \\
(2.863)\end{array}$ \\
\hline Income 4 th quartile & $\begin{array}{l}0.0115 \\
(0.727)\end{array}$ & $\begin{array}{l}-0.0291^{* * *} \\
(4.243)\end{array}$ \\
\hline Wealth 2nd quartile & $\begin{array}{l}-0.0013 \\
(0.373)\end{array}$ & $\begin{array}{l}-0.0055^{*} \\
(1.832)\end{array}$ \\
\hline Wealth 3rd quartile & $\begin{array}{l}-0.0043 \\
(1.272)\end{array}$ & $\begin{array}{l}-0.0099^{* * *} \\
(3.798)\end{array}$ \\
\hline Wealth 4th quartile & $\begin{array}{l}-0.0069 \\
(1.524)\end{array}$ & $\begin{array}{l}-0.0167^{* * *} \\
(5.547)\end{array}$ \\
\hline \multicolumn{3}{|l|}{ Wife's characteristics } \\
\hline Age & $\begin{array}{l}-0.0019^{* * * *} \\
(4.570)\end{array}$ & $\begin{array}{l}0.0057^{* * *} \\
(6.014)\end{array}$ \\
\hline Age $^{2}$ & & $\begin{array}{l}-0.0077^{* * *} \\
(8.710)\end{array}$ \\
\hline Education & $\begin{array}{l}0.0008 \\
(0.579)\end{array}$ & $\begin{array}{l}0.0283^{* * *} \\
(3.730)\end{array}$ \\
\hline Education ${ }^{2}$ & & $\begin{array}{l}-0.5187^{* * *} \\
(4.476)\end{array}$ \\
\hline Income & $\begin{array}{l}0.0155^{* * *} \\
(27.693)\end{array}$ & $\begin{array}{l}0.0230^{* * *} \\
(18.934)\end{array}$ \\
\hline Income $^{2}$ & & $\begin{array}{l}-0.0191^{* * *} \\
(5.476)\end{array}$ \\
\hline Working wife & $\begin{array}{l}-0.0849^{* * *} \\
(14.594)\end{array}$ & $\begin{array}{l}-0.1000^{* * *} \\
(20.094)\end{array}$ \\
\hline \multicolumn{3}{|l|}{ Husband's characteristics } \\
\hline Age & $\begin{array}{l}0.0007^{*} \\
(1.737)\end{array}$ & $\begin{array}{l}-0.0049^{* * *} \\
(4.287)\end{array}$ \\
\hline Age $^{2}$ & & $\begin{array}{l}0.0052^{* * *} \\
(4.729)\end{array}$ \\
\hline Education & $\begin{array}{l}-0.003 \\
(1.219)\end{array}$ & $\begin{array}{l}-0.0353^{* * *} \\
(5.476)\end{array}$ \\
\hline Education $^{2}$ & & $\begin{array}{l}0.5077^{* * *} \\
(4.541)\end{array}$ \\
\hline Income & $\begin{array}{l}-0.0104^{* * *} \\
(5.671)\end{array}$ & $\begin{array}{l}-0.0087^{* * *} \\
(9.069)\end{array}$ \\
\hline Income $^{2}$ & & $\begin{array}{l}0.0015^{* * *} \\
(9.120)\end{array}$ \\
\hline Working husband & $\begin{array}{l}0.0411^{* * *} \\
(6.920)\end{array}$ & $\begin{array}{l}0.0399^{* * *} \\
(9.483)\end{array}$ \\
\hline \multicolumn{3}{|l|}{ Background variables } \\
\hline Divorce hazard & $\begin{array}{l}-0.0869 \\
(1.047)\end{array}$ & $\begin{array}{l}-0.0833 \\
(1.116)\end{array}$ \\
\hline Female employment rate & $\begin{array}{l}0.0715 \\
(0.351)\end{array}$ & $\begin{array}{l}0.0541 \\
(0.281)\end{array}$ \\
\hline Observations & 59,389 & 59,389 \\
\hline Pseudo $R^{2}$ & 0.3413 & 0.3651 \\
\hline
\end{tabular}

Note: Marginal effects of probit estimates with robust standard errors clustered at the regional level (robust $t$-statistics in parenthesis). Each regression includes time and regional dummies.

" Significant at 10\%.

** Significant at $5 \%$.

*** Significant at $1 \%$. 
Table 3

Within-couple differentials.

\begin{tabular}{|c|c|c|c|c|c|}
\hline \multirow[t]{2}{*}{ Variables } & \multicolumn{5}{|c|}{ Dependent variable: female head } \\
\hline & $(1)$ & $(2)$ & (3) & $(4)$ & $(5)$ \\
\hline \multicolumn{6}{|l|}{ Within-couples differentials } \\
\hline Age differential (wife-husband) & $\begin{array}{l}0.00004 \\
(0.084)\end{array}$ & & & $\begin{array}{l}-0.0004 \\
(0.809)\end{array}$ & $\begin{array}{l}0.0049^{* * *} \\
(4.287)\end{array}$ \\
\hline Education differential (wife-husband) & & $\begin{array}{l}0.0306^{* * *} \\
(13.040)\end{array}$ & & $\begin{array}{l}0.0043^{* * *} \\
(2.952)\end{array}$ & $\begin{array}{l}0.0353^{* * *} \\
(5.476)\end{array}$ \\
\hline Income differential (wife-husband) & & & $\begin{array}{l}0.0102^{* * *} \\
(9.906)\end{array}$ & $\begin{array}{l}0.0101^{* * *} \\
(9.795)\end{array}$ & $\begin{array}{l}0.0087^{* * *} \\
(9.069)\end{array}$ \\
\hline \multicolumn{6}{|l|}{ Household characteristics } \\
\hline Household size & & & & & $\begin{array}{l}0.0224^{* * *} \\
(3.444)\end{array}$ \\
\hline Household size ${ }^{2}$ & & & & & $\begin{array}{l}-0.0020^{* * *} \\
(2.676)\end{array}$ \\
\hline Income 2 nd quartile & & & & & $\begin{array}{l}0.0043 \\
(1.006)\end{array}$ \\
\hline Income 3rd quartile & & & & & $\begin{array}{l}-0.0137^{* * *} \\
(2.863)\end{array}$ \\
\hline Income 4 th quartile & & & & & $\begin{array}{l}-0.0291^{* * *} \\
(4.243)\end{array}$ \\
\hline Wealth 2nd quartile & & & & & $\begin{array}{l}-0.0055^{*} \\
(1.832)\end{array}$ \\
\hline Wealth 3rd quartile & & & & & $\begin{array}{l}-0.0099 \\
(3.798)\end{array}$ \\
\hline Wealth 4th quartile & & & & & $\begin{array}{l}-0.0167 \\
(5.547)\end{array}$ \\
\hline \multicolumn{6}{|l|}{ Wife's characteristics } \\
\hline Age & & & & & $\begin{array}{l}0.0008 \\
(1.394)\end{array}$ \\
\hline Age $^{2}$ & & & & & $\begin{array}{l}-0.0077^{* * *} \\
(8.710)\end{array}$ \\
\hline Education & & & & & $\begin{array}{l}-0.007 \\
(1.164)\end{array}$ \\
\hline Education ${ }^{2}$ & & & & & $\begin{array}{l}-0.5187^{* *} \\
(4.476)\end{array}$ \\
\hline Income & & & & & $\begin{array}{l}0.0143^{* * *} \\
(12.810)\end{array}$ \\
\hline Income $^{2}$ & & & & & $\begin{array}{l}-0.0191 \\
(5.476)\end{array}$ \\
\hline Working wife & & & & & $\begin{array}{l}-0.1000 \\
(20.094)\end{array}$ \\
\hline \multicolumn{6}{|l|}{ Husband's characteristics } \\
\hline $\mathrm{Age}^{2}$ & & & & & $\begin{array}{l}0.0052^{* * *} \\
(4.729)\end{array}$ \\
\hline Education $^{2}$ & & & & & $\begin{array}{l}0.5077^{* * *} \\
(4.541)\end{array}$ \\
\hline Income $^{2}$ & & & & & $\begin{array}{l}0.0015^{* * *} \\
(9.120)\end{array}$ \\
\hline Working husband & & & & & $\begin{array}{l}0.0399 \\
(9.483)\end{array}$ \\
\hline \multicolumn{6}{|l|}{ Background variables } \\
\hline Divorce hazard & & & & & $\begin{array}{l}-0.0833 \\
(1.116)\end{array}$ \\
\hline Female employment rate & & & & & $\begin{array}{l}0.0541 \\
(0.281)\end{array}$ \\
\hline Observations & 59,389 & 59,389 & 59,389 & 59,389 & 59,389 \\
\hline Pseudo $R^{2}$ & 0.1177 & 0.1255 & 0.285 & 0.2852 & 0.3651 \\
\hline
\end{tabular}

Note: Marginal effects of probit estimates with robust standard errors clustered at the regional level (robust $t$-statistics in parenthesis). Each regression includes time and regional dummies.

* Significant at $10 \%$

** Significant at 5\%.

*** Significant at $1 \%$. 
wealth quartiles. The second and third sets include individual characteristics of the wife and the husband, respectively, namely each spouse's age, level of education, income, and occupational status (the latter as a dummy variable taking value 1 if the individual is working, 0 otherwise). The last set controls for aggregate background variables: namely, the divorce hazard and the female employment rate, computed at the regional level.

Column 1 shows that the probability that the wife is responsible for decisions increases with the size of the household in a concave fashion. Standard economic characteristics such as household income and wealth do not appear to matter except for the positive effect of the second quartile for income. Once we turn to individual characteristics, we find that age matters negatively for the wife, while it has a positive but barely significant effect for the husband: according to the estimates on average every additional year of age of the wife reduces the dependent variable by 0.0019 , while every additional year of age of the husband increases it by 0.0007 . Education is not significant, both for the wife and the husband. When entered separately, each spouse's earnings appear to matter in the expected direction: the wife's decision-making responsibility increases with her income and decreases with that of the husband. More specifically, an increase of a thousand euro in the wife's income substantially increases the dependent variable by 0.0155 , while the same amount added to the income of her husband reduces it by 0.0104 .

At this stage we can already test the implications of the household production framework using information on each spouse's occupational status that should capture the degree of specialization within the family. We find that a working husband implies a larger probability that the wife is responsible, while a working wife decreases such probability, suggesting that after controlling for everything else indeed there may be a division of tasks operating within the family, with certain chores being allocated to the spouse who has more time to devote to decision making. In other words, in light of the simple analytical framework sketched in Section 3, time availability, reflecting specialization patterns, is an important consideration in the allocation of responsibility. ${ }^{13}$

Finally, the fact that the family lives in a region characterized by a large divorce hazard or by a high female occupational level exerts no significant impact on women's position.

In Column 2 of Table 2 we investigate the possibility that the effect of individual characteristics involving age, education and income may have a non-linear influence on the dependent variable. Therefore we add squared terms for all the three variables, both for the wife and the husband. The resulting picture is profoundly altered, not only with respect to each of these variables, but also with respect to the variables capturing household characteristics. Namely, the impact of the wife's age is confirmed, but its influence is non-linear, with wives of an intermediate age (at around age 37) more likely to find themselves in a position of responsibility, rather than older ones as suggested by the linear specification. The non-linear specification reveals that the husband's age also has a highly significant non-linear influence, with women's responsibility being lower when the husband is middle-aged (48 years of age). In other words, for very young and very old husbands (possibly for very different reasons having to do with culture and health respectively) it is more likely that wives decide. Turning to education, we again find that for wives its effect is not linear, with maximum women's responsibility reached at the high school level, suggesting that very educated women are not likely to make decisions, but the same applies to poorly educated ones. The effect is not linear for husbands' education as well, with minimum women's responsibility being associated with a relatively high (between high school and college) level of their spouse's education. ${ }^{14}$ The impact of individual income is also modified in the non-linear specification: for the wife's income the positive effect of the linear term is confirmed, but is accompanied by a negative effect of the square, which suggests that wives with a large income may actually prefer to delegate. We find a non-linear, but now convex effect of the husbands' income. Interestingly, accounting for the non-linear effect of individual characteristics also modifies previous conclusions regarding household variables: while the influence of household size is confirmed, Column 2 reveals that women's responsibility is decreasing in total household income and wealth, a feature which was obscured in Column $1 .^{15}$ To sum up, the comparison between Columns 1 and 2 shows that not only individual characteristics concerning age, education, income, and occupational status matter, but also that their effect is non-linear and that household income and wealth do play a role, suggesting that the first model is misspecified.

Since the two models in Table 2 are nested, we statistically test for the joint significance of the added terms: the evidence confirms that the two models are statistically different from each other. Similarly, a test for the joint significance of the set of controls for each spouse's characteristics confirms that both the husbands' and wives' characteristics retain independent roles in determining which partner holds responsibility for finances.

In sum, in Table 2 we have replicated (Column 1) and extended (Column 2) the benchmark model stemming from the above-mentioned literature that has tried to investigate, as we do, the determinants of intra-household decision responsibility when it can be measured by a directly observed sort of dependent variable. In order to test more effectively the

\footnotetext{
13 Woolley (2003) controls for a similar dummy variable indicating whether or not the female partner is in full-time paid employment and finds it is never significant over a variety of financial decisions.

14 Education retains a similar effect even if we express the available information as years of education, rather than levels.

15 Total household income is the sum of the incomes of all the household members, so that it differs from the sum of husband and wife incomes only in the presence of additional working members in the household. As a result, the difference is in most cases not that large and this might well explain why in the first specification total income is not statistically significant. Introducing the quadratic term for the individual levels contributes to make such difference no longer negligible, allowing total income to retain an independent role with respect to the spouses' individual incomes. Our main results persist also under different model specifications concerning income and wealth, i.e., considering their linear and quadratic terms or their logarithms (which reduce the impact of possible outliers).
} 
implications of the bargaining approach introduced in Section 3, in Table 3 we rearrange the covariates introduced in the non-linear specification in Column 2 of Table 2 in such a way that differentials within the couples, with respect to age, education and income, are emphasized. In this way we can verify if any dimension of marriage heterogamy is really significantly associated with the probability that the wife is responsible. Operationally, we first introduce as a regressor a variable measuring the difference in years between the age of the wife and that of the husband. The second regressor is the difference between the wife's and the husband's level of education, the third is similarly defined for their respective income. Summary statistics for each kind of differential are presented in Table 1. We regress the same binary dependent variable employed in Table 2 on these differentials. At the same time, by controlling for employment status, we can test whether the bargaining and the specialization approach are alternative or complementary explanations.

Another advantage of the specification in Table 3 is that it allows a direct comparison between our results and the large literature mentioned in Section 2 that has tried to assess the influence of decision responsibility on a variety of economic and non-economic decisions and, in the absence of any direct measure, has relied on proxies of each spouse's relative position. These proxies are often dummies capturing the fact that a spouse may or may not have a higher age, education, or income level. Exploiting the fact that we do have a direct measure of decision-making responsibility, as well as precise information about individual characteristics, we capture marriage heterogamy along these three dimensions not simply as dummies but as differentials.

We start by reporting the results of simple regressions involving each differential, one by one, and then we estimate a fourth regression including the three differentials together. This sort of univariate, preliminary exercise is meant to facilitate the exposition of the intuition behind the underlying links. Since the average wife-husband differentials are negative, in interpreting results we have to keep in mind that an increase in the differentials means that the wife's characteristics in terms of age, education and income become closer or higher that the corresponding husband's. In Column 1 of Table 3 we consider the age differential. In principle, one might expect that the older is the wife relative to the husband the more likely it is that she is the decision maker, because age may reflect experience, savviness, and reliability. However, the effect is not significant. In Column 2 we evaluate the education differential, which may reflect similar considerations. Indeed now we find that this differential is positively associated with decision responsibility: the more similar or the higher is the wife's level of education relative to the husband, the more likely is that she decides. The same occurs for their income differential in Column 3, while Column 4 shows that the relevance of both the education and the income differentials is confirmed when accounting for the three dimensions together, even though the size of the effect of education is smaller once income is accounted for, which signals that the two types of differences are correlated. However, we are interested in combining this evidence with what we know from Table 2 about a broader set of potential determinants of decision responsibility.

These preliminary considerations are those behind our preferred specification, which we introduce in Column 5 of Table 3 where, as previously explained, we simply rearrange the covariates introduced in the non-linear specification in Column 2 of Table 2 in such a way that differentials within the couples, with respect to age, education and income, are emphasized. ${ }^{16}$ It is worth emphasizing again that the main purpose of the exercise, which we perform for expositional ease, is twofold. First of all, in comparison with Table 2, Column 2, we can now fully capture the effect of heterogeneities within the couple. Second, by comparing it with the previous columns of Table 3, we can evaluate how the relationship between differentials and our observed measure of decision-making responsibility is affected by the additional covariates.

Interestingly, now all the three dimensions of the within-couple differentials are highly significant and with the expected sign, suggesting that the relative responsibility for decisions within the household is determined by heterogeneities which are not simply associated with earnings but also with education as well as age. Table 3 highlights that additional responsibility for wives does not come from their individual characteristics per se, but from the relative distance from the husbands' corresponding characteristics.

While this evidence is consistent with a bargaining model of intra-family relations, it is important to stress that our previous findings supporting a specialization story are still confirmed. To shed more light on the apparent coexistence of both patterns in our data, we run a set of additional regressions (not reported for brevity). First, we add to the benchmark specification in Table 3, Column 5 a set of interaction terms between each differential and the working wife dummy. The fact that none of the interactions displays a significant effect confirms that both the bargaining and the specialization channel exert a separate influence on the dependent variable. Alternatively, we re-estimate the same regression on two separate subsamples: the first only includes households with a working wife, the second the remaining households. The two sub-samples are respectively designed to include non-specialized and specialized households. ${ }^{17}$ The effects of the three differentials remain significant in both sub-samples, with a $5 \%$ (rather than $1 \%$ ) significance level for the age differential in both cases and with a smaller size of the marginal effects in the specialized sub-sample. This confirms once again that even specialized

\footnotetext{
16 The probit estimated in Table 3,P(Y $\left.Y_{i j}=1 \mid \mathbf{X}_{i j}\right)=\phi\left(\alpha\left(\mathbf{W}_{i j}-\mathbf{H}_{i j}\right)+\beta \mathbf{W}_{i j}+\gamma \mathbf{W}_{i j}^{2}+\delta \mathbf{H}_{i j}^{2}+v \mathbf{H h o l d}_{i j}+\mathbf{C}_{j}\right)$ can be rearranged as $P\left(Y_{i j}=1 \mid \mathbf{X}_{i j}\right)=\phi\left((\alpha+\beta) \mathbf{W}_{i j}-\right.$ $\alpha \mathbf{H}_{i j}+\gamma \mathbf{W}_{i j}^{2}+\delta \mathbf{H}_{i j}^{2}+v$ Hhold $_{i j}+\mathbf{C}_{j}$ ), which corresponds to the specification reported in Table 2, where $\mathbf{W}, \mathbf{H}$, and Hhold represent the wife's, husband's and household's characteristics respectively and $\mathbf{C}$ the remaining controls.

17 See Amuedo-Dorantes et al. (2010) for a similar empirical strategy.
} 
Table 4

Average marginal effect of the differentials at each year.

\begin{tabular}{|c|c|c|c|c|c|c|}
\hline \multirow[t]{2}{*}{ Year } & \multicolumn{2}{|l|}{ Age differential } & \multicolumn{2}{|c|}{ Education differential } & \multicolumn{2}{|l|}{ Income differential } \\
\hline & $\begin{array}{l}\text { Average } \\
\text { marginal effect } \\
(95 \% \text { C.I. })\end{array}$ & $\begin{array}{l}H_{0}: d y / d x \text { at } t \\
\neq d y / d x \text { at } \\
1989\end{array}$ & $\begin{array}{l}\text { Average } \\
\text { marginal effect } \\
(95 \% \text { C.I. })\end{array}$ & $\begin{array}{l}H_{0}: d y / d x \text { at } t \\
\neq d y / d x \text { at } \\
1989\end{array}$ & $\begin{array}{l}\text { Average } \\
\text { marginal effect } \\
\text { (95\% C.I. }\end{array}$ & $\begin{array}{l}H_{0}: d y / d x \text { at } t \\
\neq d y / d x \text { at } \\
1989\end{array}$ \\
\hline 1989 & $\begin{array}{l}0.0019 \\
(0.0011 ; 0.0027)\end{array}$ & & $\begin{array}{l}0.0134 \\
(0.0076 ; 0.0192)\end{array}$ & & $\begin{array}{l}0.0034 \\
(0.0022 ; 0.0047)\end{array}$ & \\
\hline 1991 & $\begin{array}{l}0.0016 \\
(0.0008 ; 0.0024)\end{array}$ & -0.712 & $\begin{array}{l}0.0114 \\
(0.0060 ; 0.0167)\end{array}$ & -0.748 & $\begin{array}{l}0.0029 \\
(0.0018 ; 0.0040)\end{array}$ & -0.948 \\
\hline 1993 & $\begin{array}{l}0.0057 \\
(0.0026 ; 0.0089)\end{array}$ & $2.381^{* * *}$ & $\begin{array}{l}0.0407 \\
(0.0209 ; 0.0605)\end{array}$ & $2.703^{* * *}$ & $\begin{array}{l}0.0104 \\
(0.0085 ; 0.0122)\end{array}$ & $7.409^{* * *}$ \\
\hline 1995 & $\begin{array}{l}0.0058 \\
(0.0029 ; 0.0088)\end{array}$ & $2.626^{* * *}$ & $\begin{array}{l}0.0416 \\
(0.0240 ; 0.0592)\end{array}$ & $3.144^{* * *}$ & $\begin{array}{l}0.0106 \\
(0.0084 ; 0.0128)\end{array}$ & $6.520^{* * *}$ \\
\hline 1998 & $\begin{array}{l}0.0055 \\
(0.0029 ; 0.0082)\end{array}$ & $2.698^{* * *}$ & $\begin{array}{l}0.0395 \\
(0.0217 ; 0.0572)\end{array}$ & $2.880^{* * *}$ & $\begin{array}{l}0.0101 \\
(0.0077 ; 0.0125)\end{array}$ & $5.426^{* * *}$ \\
\hline 2000 & $\begin{array}{l}0.0098 \\
(0.0053 ; 0.0143)\end{array}$ & $3.462^{* * *}$ & $\begin{array}{l}0.0699 \\
(0.0442 ; 0.0957)\end{array}$ & $4.301^{* * *}$ & $\begin{array}{l}0.0178 \\
(0.0149 ; 0.0208)\end{array}$ & $9.573^{* * *}$ \\
\hline 2002 & $\begin{array}{l}0.0103 \\
(0.0055 ; 0.0150)\end{array}$ & $3.459^{* * *}$ & $\begin{array}{l}0.0732 \\
(0.0458 ; 0.1007)\end{array}$ & $4.275^{* * *}$ & $\begin{array}{l}0.0187 \\
(0.0159 ; 0.0214)\end{array}$ & $10.943^{* * *}$ \\
\hline 2004 & $\begin{array}{l}0.0112 \\
(0.0060 ; 0.0164)\end{array}$ & $3.522^{* * *}$ & $\begin{array}{l}0.0799 \\
(0.0520 ; 0.1077)\end{array}$ & $4.672^{* * *}$ & $\begin{array}{l}0.0203 \\
(0.0174 ; 0.0233)\end{array}$ & $11.185^{* * *}$ \\
\hline 2006 & $\begin{array}{l}0.0103 \\
(0.0056 ; 0.0150)\end{array}$ & $3.501^{* * *}$ & $\begin{array}{l}0.0731 \\
(0.0491 ; 0.0971)\end{array}$ & $4.875^{* * *}$ & $\begin{array}{l}0.0186 \\
(0.0155 ; 0.0217)\end{array}$ & $9.622^{* * *}$ \\
\hline 2008 & $\begin{array}{l}0.0109 \\
(0.0056 ; 0.0162)\end{array}$ & $3.345^{* * *}$ & $\begin{array}{l}0.0776 \\
(0.0507 ; 0.1046)\end{array}$ & $4.671^{* * *}$ & $\begin{array}{l}0.0198 \\
(0.0168 ; 0.0227)\end{array}$ & $10.957^{* * *}$ \\
\hline 2010 & $\begin{array}{l}0.0134 \\
(0.0071 ; 0.0197)\end{array}$ & $3.604^{* * *}$ & $\begin{array}{l}0.0954 \\
(0.0611 ; 0.1296)\end{array}$ & $4.689^{* * *}$ & $\begin{array}{l}0.0243 \\
(0.0210 ; 0.0276)\end{array}$ & $12.543^{* * *}$ \\
\hline
\end{tabular}

Note: For each differential, the table reports the average marginal effects at each year in sample (95\% confidence intervals in parenthesis) and the $t$-statistics for the marginal effect being statistically higher than the marginal effect at the initial year (1989).

* Significant at $10 \%$.

*** Significant at $5 \%$.

*** Significant at $1 \%$.

families where the wife is not working still assign financial responsibility on the basis of the relative characteristics of the spouses, ${ }^{18}$ even though the impact of the differentials is lower.

In order to investigate the role of the within-couple differentials along the time dimension, for the specification in Column 5 of Table 3 we also compute the average marginal effect of each differential for each year in the sample. We report results for the age, education, and income differential in Table 4. The average marginal effects are increasing over time for all three differentials. The table also reports the $t$-statistics for the marginal effects being statistically higher than the marginal effect at the initial year (1989), which reveal that the differentials are significantly higher than 1989 ones. To ease the reading of the results, the estimated marginal effects together with their confidence intervals are represented graphically in Fig. 4. The evidence is of an increasing relevance of each differential over time, although the estimates for the age differential are slightly less precise than those obtained for the education and income differentials.

To conclude, decision-making within the family appears to be affected by each of the factors that may determine heterogeneities between spouses. Strictly economic factors are important, but education and age also matter. In other words, the intra-household allocation of responsibility for finances appears to be not just a question of money, but also of other not purely economic individual characteristics. This pattern is intensifying over time. At the same time, there is also evidence that the allocation of decision responsibility responds to the patterns of specialization within the family.

A final word of caution concerns the fact that our results may fail to identify a causal relationship running from observable differences within marriages to female control over financial decision making, both because of potential reverse causality and because of omitted variables. These concerns are at least partially addressed through the robustness checks we perform in the next section.

\section{Robustness checks}

In this section we consider a number of variations and extensions of the previous analysis in order to check its robustness. We will consider as a reference Column 5 of Table 3, i.e., the specification that emphasizes within-household differences and at the same time allows for a non-linear impact of individual characteristics. We start by running a logit and a linear probability model. In both cases, the estimates obtained for the age, education and income differentials are remarkably stable

\footnotetext{
18 As a further check, we also run the same regression over a sub-sample of families where the wife falls under the more narrow definition of housewife, thus capturing an extreme degree of specialization. We find that the income differential is still significant even for this sample, while age and education no longer matter. We do not report these additional regressions for brevity.
} 
Age
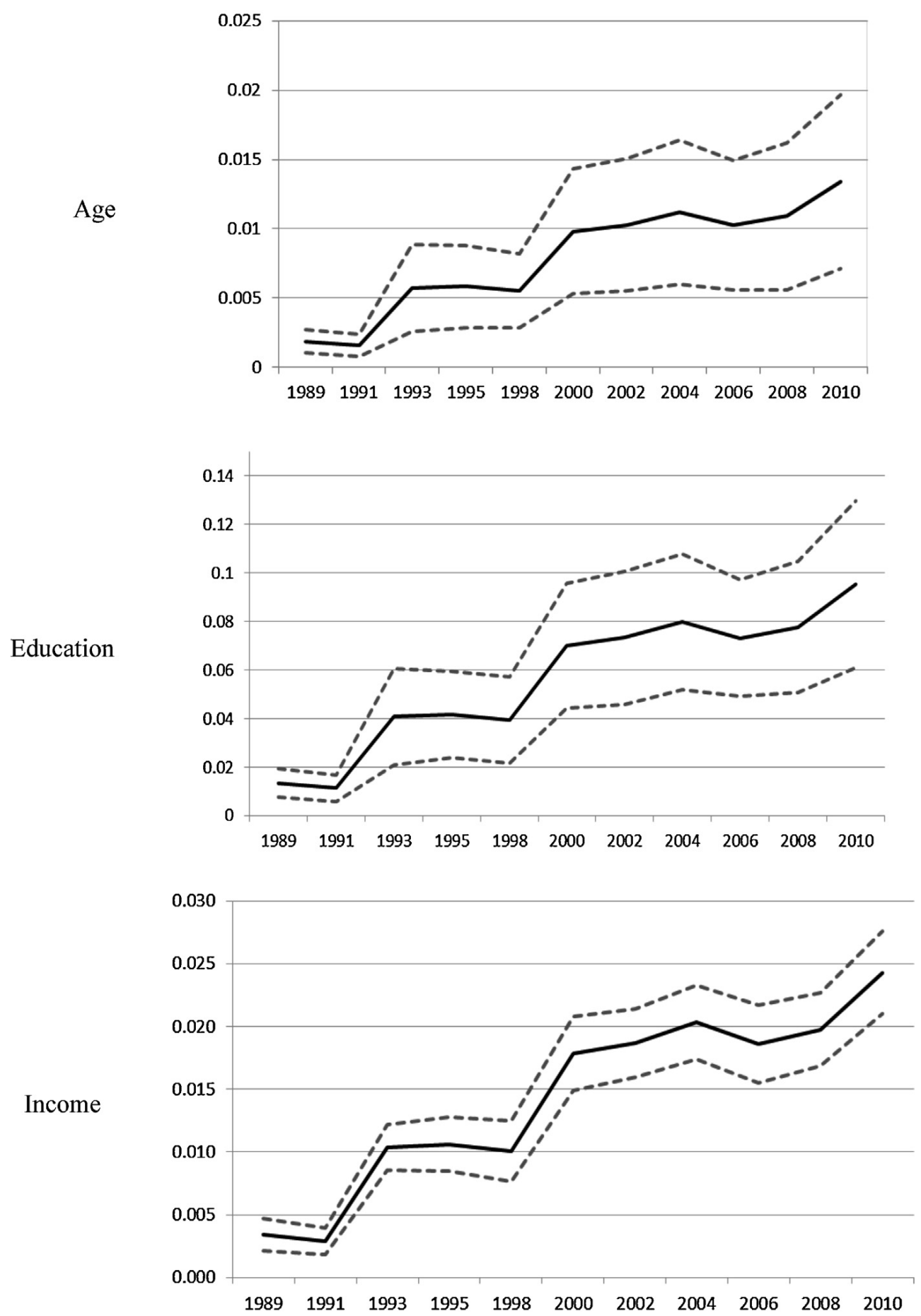

Fig. 4. Average marginal effects with confidence intervals.

Note: For each differential, the graph plots the average marginal effects at each year in sample and the corresponding $95 \%$ confidence interval.

in terms of sign, statistical significance and magnitude. We do not report these results for brevity. All tables of this section only report the marginal effects of the regressors for the differentials and the employment status dummies, while those of the other variables introduced so far (i.e., household, wife's and husband's characteristics, and background variables) are omitted for brevity.

\subsection{Type of tasks}

The households' financial and economic decisions range from simple chores such as paying bills to more complex choices such as the asset allocation of the family portfolio. In this section we test whether the probability of the wife being responsible is higher when financial and economic decisions reduce to very simple tasks. To be noticed is that this amounts to another test of the household production cum specialization framework even though, contrary to Dobbelsteen and Kooreman (1997) 
Table 5

Simple financial tasks.

\begin{tabular}{|c|c|}
\hline Variables & Dependent variable: female head \\
\hline \multicolumn{2}{|l|}{ Within-couples differentials } \\
\hline Age differential (wife-husband) & $\begin{array}{l}0.0107^{* * *} \\
(2.927)\end{array}$ \\
\hline Education differential (wife-husband) & $\begin{array}{l}0.0800^{* * *} \\
(3.346)\end{array}$ \\
\hline Income differential (wife-husband) & $\begin{array}{l}0.0213^{* * * *} \\
(8.58)\end{array}$ \\
\hline \multicolumn{2}{|l|}{ Additional controls } \\
\hline Working wife & $\begin{array}{l}-0.2367^{* * *} \\
(19.221)\end{array}$ \\
\hline Working husband & $\begin{array}{l}0.1182^{* * *} \\
(9.284)\end{array}$ \\
\hline Simple choices & $\begin{array}{l}0.0057 \\
(0.79)\end{array}$ \\
\hline Household characteristics & Yes \\
\hline Wife's characteristics & Yes \\
\hline Husband's characteristics & Yes \\
\hline Background variables & Yes \\
\hline Observations & 19,400 \\
\hline Pseudo $R^{2}$ & 0.3271 \\
\hline
\end{tabular}

Note: Marginal effects of probit estimates with robust standard errors clustered at the regional level (robust $t$-statistics in parenthesis). Each regression includes time and regional dummies.

* Significant at $10 \%$.

Significant at $5 \%$.

*** Significant at $1 \%$.

and Woolley (2003), we do not have information on how, within the same family, responsibility is allocated for different types of decisions. However, since the 2000 wave the SHIW supplies some information that we can exploit as follows. We can define a dummy "simple tasks" taking value 1 if the household declares to use banking services only for paying bills (including housing rent and mortgages) and/or for wage crediting, and 0 otherwise. This implies that activities such as securities management or trading, asset administration and insurances management are not performed by the household. As shown in Table 1, 78.65\% of the households in our sample are confined to simple choices. Regression results, reported in Table 5, do not change substantially in the presence of the dummy, whose effect is positive but not significant. Therefore, contrary to the implications of the specialization story, we cannot conclude that wives are more likely to be responsible if only simple tasks are at issue. ${ }^{19}$ On the other hand, the negative influence of the wife's employment status is confirmed.

\subsection{Occupational status}

In this sub-section we evaluate the implications of a more detailed description of the individual positions in the labor market. So far we have considered two dummy variables capturing the fact that the wife and the husband are employed and, in support of the fact that time allocation and specialization contribute to determine decision responsibility, we have found a negative influence for the first and a positive one for the second. However, this specification does not highlight within-family differences in occupational status. Therefore in Table 6 we replace this information with alternative, more specific sets of dummies. In Column 1 we introduce three separate dummies. The first one captures the case when the wife is the only one who is employed. The second captures the case when the husband is the only one who is employed. The third captures the case when both spouses do not work, uncovering the potential presence of an interaction between their respective statuses. ${ }^{20}$ The effect of the first two dummies confirms what previously found, while the positive effect of the third adds that when both spouses do not work the probability that the wife is responsible increases.

In Column 2 we evaluate more explicitly the working condition of each spouse, including dummies for being an employee, self-employed, or retired. We also control for the status of housewife. The results suggest that for both spouses being an employee rather than self-employed does not modify the effect of being at work on the dependent variable. Being retired has a negative effect for the wife and a non-significant one for the husband, possibly because of the older age of the couples in this status. Starting from the 2000 wave the SHIW also provides information about job tenure and part-time occupation. For this restricted sample, in Column 3 we find that being tenured confirms for both wives and husbands the general impact of the original dummy for being at work, while having a part-time position shows opposite signs, suggesting that both wives

\footnotetext{
19 We also run separate regressions over two sub-samples of households, the first involved only in simple tasks, the second in all tasks. The positive effect of the differentials is confirmed for both sub-samples. Likewise, the negative effect of the presence of a working wife is confirmed.

20 All information concerning occupational status refer to the condition of the respondent during most of the survey year.
} 
Table 6

Finer measures of occupational status.

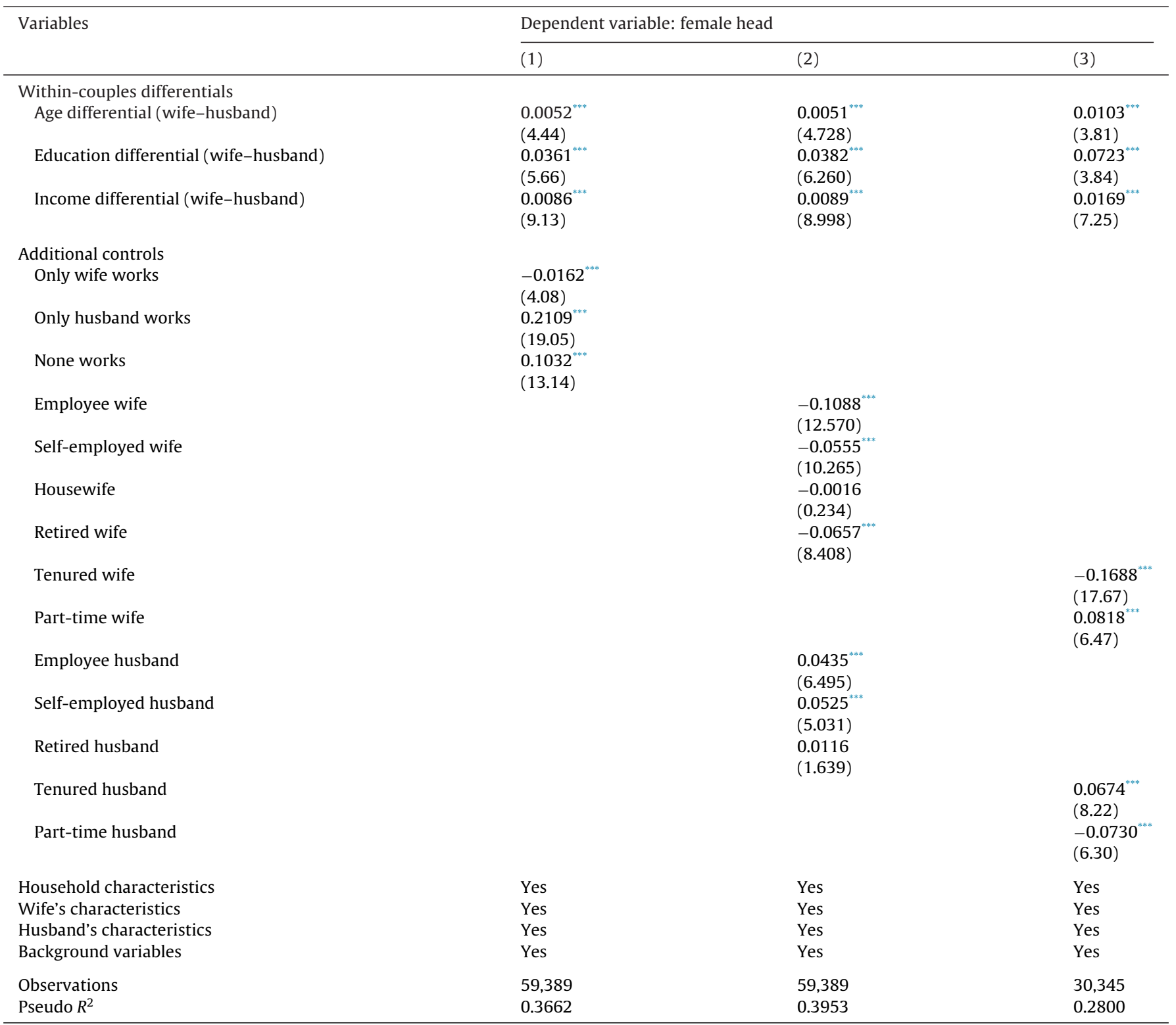

Note: Marginal effects of probit estimates with robust standard errors clustered at the regional level (robust $t$-statistics in parenthesis). Each regression includes time and regional dummies.

* Significant at $10 \%$.

** Significant at 5\%.

*** Significant at $1 \%$.

and husbands in this intermediate status tend to behave more like not-working rather than working ones. Taken together, these findings broadly confirm what previously found in Table 3, i.e., an underlying specialization pattern that attributes more responsibility to the partner with more available time. At the same time, the main conclusion regarding the impact of within-couple differentials is not affected, as their marginal effects remain remarkably stable in terms of size and significance across all specifications. However, it should be noticed that when the sample is restricted to the $2000-2010$ period their size nearly doubles, confirming that their influence might be increasing over time.

\subsection{Marriage vs. cohabitation}

So far our sample included only legally married couples. Over time, however, cohabitation has become a more and more widespread phenomenon. Exploiting the fact that the SHIW also surveys cohabiting couples that are not married, we repeat our estimation for a sample of non-married couples. The number of cohabiting couples surveyed has increased from zero in 1989 to 146 (around 3\% of the couples) in 2010. Yet, the cohabiting households are only 808 over the total period, so that under-sampling and under-reporting may be serious issues regarding these data. While the number of observations is 
Table 7

Alternative samples: unmarried couples and older couples.

\begin{tabular}{|c|c|c|c|}
\hline \multirow[t]{2}{*}{ Variables } & \multicolumn{3}{|c|}{ Dependent variable: female head } \\
\hline & Cohabiting & Age 51-61 & Age $50+$ \\
\hline \multicolumn{4}{|l|}{ Within-couples differentials } \\
\hline Age differential (wife-husband) & $\begin{array}{l}0.0462^{* * *} \\
(3.584)\end{array}$ & $\begin{array}{l}0.0026 \\
(0.690)\end{array}$ & $\begin{array}{l}0.0088^{* * *} \\
(4.164)\end{array}$ \\
\hline Education differential (wife-husband) & $\begin{array}{l}-0.3471^{* * *} \\
(3.356)\end{array}$ & $\begin{array}{l}0.0255^{* *} \\
(2.432)\end{array}$ & $\begin{array}{l}0.0274^{* * *} \\
(4.238)\end{array}$ \\
\hline Income differential (wife-husband) & $\begin{array}{l}0.0499^{* * *} \\
(6.674)\end{array}$ & $\begin{array}{l}0.0077^{* * *} \\
(8.307)\end{array}$ & $\begin{array}{l}0.0088^{* * *} \\
(10.057)\end{array}$ \\
\hline \multicolumn{4}{|l|}{ Additional controls } \\
\hline Working wife & $\begin{array}{l}-0.5081^{* * *} \\
(9.031)\end{array}$ & $\begin{array}{l}-0.0861^{* * *} \\
(23.413)\end{array}$ & $\begin{array}{l}-0.0625^{* * *} \\
(27.415)\end{array}$ \\
\hline Working husband & $\begin{array}{l}0.2088^{* * *} \\
(2.867)\end{array}$ & $\begin{array}{l}0.0300^{* * *} \\
(5.403)\end{array}$ & $\begin{array}{l}0.0386^{* * *} \\
(5.855)\end{array}$ \\
\hline Household characteristics & Yes & Yes & Yes \\
\hline Wife's characteristics & Yes & Yes & Yes \\
\hline Husband's characteristics & Yes & Yes & Yes \\
\hline Background variables & Yes & Yes & Yes \\
\hline Observations & 808 & 20,906 & 33,917 \\
\hline Pseudo $R^{2}$ & 0.3687 & 0.3901 & 0.3899 \\
\hline
\end{tabular}

Note: Marginal effects of probit estimates with robust standard errors clustered at the regional level (robust $t$-statistics in parenthesis). Each regression includes time and regional dummies.

* Significant at $10 \%$.

Significant at $5 \%$.

*** Significant at $1 \%$.

greatly reduced, this living arrangement is likely to expanding even more in the future, so it is important to understand if it matters for the allocation of responsibility. The fact that the sample presents a much larger proportion of female heads, $41.8 \%$, preliminarily suggests that it does. To be noticed is that in the cohabiting sample average age is lower both for males and females, while average education is higher and the education differential is now in favor of females.

Previous research has shown that, relative to unmarried couples, married couples do behave differently. For instance, over a sample of Canadian couples Woolley (2003) finds that for common law couples it is more likely that the main financial account of the household is in the woman's name, possibly because common law couples tend to be less likely to adhere to a traditional division of labor. However, Amuedo-Dorantes et al. (2010) document that specialization patterns are present even among non-married couples. ${ }^{21}$ From the first column of Table 7 we can see that our results are in fact quite different from those obtained for married couples. The differentials within the couple remain very significant, but the education differential now shows a negative sign, suggesting that for this sample women that have similar or more education than their partners are less likely to make decisions. Possibly, this novelty could be attributed to the fact that these couples are more educated than the rest. At the same time, the working wife dummy continues to exert a negative influence, suggesting that even in this sample specialization affects decision responsibility. The effect of the wives' education and income also tends to differ from the case of married couples. Moreover, the (unreported) effect of family income is no longer significant. While the latter finding could indicate that non-married couples do not pool their earnings, at the same time their joint wealth is still playing a clear role. To sum up, despite the small size of the sample involved, it is clear that the institution of marriage exerts a decisive influence on intra-family decision processes. ${ }^{22}$ One issue that deserves further exploration is whether or not the decision itself to tie the knot, and the clear time evolution of its frequency, may itself reflect the changing nature of the battle of the sexes.

\subsection{Two older samples}

Most of the existing studies on the determinants of decision making are conducted within restricted samples including only older couples. This is the case for studies based both on the US HRS and the Mexican MHS. As mentioned in the literature

\footnotetext{
21 More specifically, they suggest that income pooling may serve as a form of compensation for the female partners' greater specialization in household production and find that indeed for specialized couples income pooling is more frequent where commercial domestic services (a substitute for household production) are more expensive, while the same is not true for non-specialized couples. The result holds even after splitting the sample between married and non-married couples.

22 We also run a regression over a sample including both the cohabitating and the married couples, adding a dummy variable identifying married couples. The effects of the differentials are similar to those in the married sample, while the coefficient of the new dummy is negatively significant, pointing to a lower probability that the woman is responsible within married couples. This is not surprising given the small size of the cohabiting sample. This comparison suggests that the results in Table 3, and in particular the positive role of the education differential, are not driven by sample selection.
} 
Table 8

Dummy measures of within-couple differences.

\begin{tabular}{|c|c|c|c|c|c|}
\hline \multirow[t]{2}{*}{ Variables } & \multicolumn{5}{|c|}{ Dependent variable: female head } \\
\hline & (1) & $(2)$ & (3) & (4) & (5) \\
\hline \multicolumn{6}{|c|}{ Dummies for within-couples differences } \\
\hline Wife older & $\begin{array}{l}0.0133^{* * *} \\
(2.898)\end{array}$ & & & $\begin{array}{l}0.0115^{* *} \\
(2.032)\end{array}$ & $\begin{array}{l}0.0067 \\
(1.322)\end{array}$ \\
\hline Wife more educated & & $\begin{array}{l}0.0487^{* * *} \\
(10.410)\end{array}$ & & $\begin{array}{l}0.0049 \\
(0.773)\end{array}$ & $\begin{array}{l}0.0061 \\
(1.056)\end{array}$ \\
\hline Wife earns more & & & $\begin{array}{l}0.4945^{* * *} \\
(23.044)\end{array}$ & $\begin{array}{l}0.3580^{* * *} \\
(17.897)\end{array}$ & $\begin{array}{l}0.2714^{* * * *} \\
(13.606)\end{array}$ \\
\hline \multicolumn{6}{|l|}{ Additional controls } \\
\hline Working wife & & & & $\begin{array}{l}-0.1145^{* * *} \\
(22.778)\end{array}$ & $\begin{array}{l}-0.1098^{* * *} \\
(21.042)\end{array}$ \\
\hline Working husband & & & & $\begin{array}{l}0.0370^{* * *} \\
(6.384)\end{array}$ & $\begin{array}{l}0.0355^{* * *} \\
(7.312)\end{array}$ \\
\hline Household characteristics & No & No & No & No & Yes \\
\hline Husband's characteristics & No & No & No & Yes & Yes \\
\hline Background variables & No & No & No & No & Yes \\
\hline Observations & 59,389 & 59,389 & 59,389 & 59,389 & 59,389 \\
\hline Pseudo $R^{2}$ & 0.1179 & 0.1219 & 0.2684 & 0.337 & 0.3568 \\
\hline
\end{tabular}

Note: Marginal effects of probit estimates with robust standard errors clustered at the regional level (robust $t$-statistics in parenthesis). Each regression includes time and regional dummies.

Significant at $10 \%$.

** Significant at $5 \%$.

*** Significant at $1 \%$.

review, the 1992 wave of the US HRS only includes individuals in the 51-61 age range. Unsurprisingly, over these data both Elder and Rudolph (2003) and Friedberg and Webb (2006) find no significance for age differentials. The same irrelevance of age is found by Lührmann and Maurer (2007) over the 2003 wave of the Mexican MHS, which covers the over-50 population. For the sake of comparison, we replicate our analysis first for a sub-sample such that at least one of the spouses falls within the 51-61 age-range, and then for a sub-sample such that at least one of the two is over-50 (however, it has to be kept in mind that our Italian sample includes eleven waves covering 22 years, rather than a single wave as in the other cases). The second column of Table 7 shows that, as expected from the US evidence, for the 51-61 year-old the age differential remains positive but loses its significance, while contrary to the Mexican case it retains it for the over-50 year-old. To be noticed is that the latter sample is quite large relative to the former (33,917 observations vs. 20,906) and naturally involves more variability along the age dimension. The impact of education and income differentials resembles that of the complete sample and the same holds for family size, income and wealth. Overall, these results are not surprising but provide an informative comparison with results obtained by others for older individuals. To conclude, even over these samples the significance of the working wife dummy is confirmed.

\subsection{Dummy measures for within-household heterogeneity}

In Table 8 we start by replicating the set of regressions presented in Table 3 using alternative measures for withinhousehold heterogeneity, defined as three dummies capturing the fact that the wife is older, or is more educated, or earns more than her husband. While these dichotomous measures are of course coarser than the ones used so far, they are often employed in the literature. ${ }^{23}$ Columns $1-3$ show that the fact that the wife is older, or more educated, or earns more (where each dimension is considered one by one) increases her responsibility in making decisions. In Column 4 the dummies are entered together with the spouses' characteristics at the expense of the significance of the second dummy but, when in Column 5 we retain our full specification, we find that the dummies for the wife being older or more educated are never significant. This exercise questions the ability of dichotomous measures to proxy for degrees of decision responsibility when the regression is correctly specified. Moreover, it implies that adding dummies and spouses' individual variables in regressions not including variables such as household income and wealth may induce misspecification.

By comparing these results with those obtained in the previous section, we can conclude that measuring the degree of heterogamy within couples with precise differential measures rather than with dummies leads to more clear-cut and powerful conclusions.

\footnotetext{
${ }^{23}$ For a similar dependent variable see Elder and Rudolph (2003); for a variety of alternative ones, see Lundberg et al. (2003), Lundberg and Ward-Batts (2000), Thomas (1994), Heaton (2002), Teachman (2002), Pericoli and Ventura (2012) and Bertocchi et al. (2011).
} 


\section{Conclusion}

Based on a dataset drawn from the Bank of Italy SHIW we empirically study the determinants of the economic and financial decision making within households on the basis of a unique, repeatedly collected direct measure of actual responsibility in family choices. Our main findings are twofold.

First, we find that the probability that the wife is responsible for economic and financial decisions increases as the wife characteristics in terms of age, education and income become closer or even higher that the corresponding husband's ones. This implies that a bargaining framework can account for the allocation of decision-making responsibility over economic and financial issues, and that strictly economic differences within the couple are not the only factors: differences in age and education, that should make individuals more knowledgeable, more experienced, and savvier, are also shown to matter.

Second, we also find that the probability that the wife is responsible is lower when she is employed, which supports the validity of the household production approach. Because of a division of tasks operating within the family, more responsibility tends to be assigned to the wife since she has more time to devote to financial tasks.

To recognize all the determinants of decision responsibility is crucial to understand how the latter affects a wide variety of economic and non-economic decisions, and how gender-based policies should be designed. Our results show that the allocation of decision-making responsibility responds both to a wide array of differentials that can be associated with the relative bargaining power of the partners, but also to the division of labor within the couple, reflecting complex interactions which cannot fully be accounted for by a single analytical framework.

Our results stress the potential relevance of crucial social trends that may prove faster than purely economic ones in the near future. In fact, even during the period we consider, female educational achievements relative to those of males, as well as marriage markets and matching patterns, have evolved at least as much as the economic position of women in the labor market. Even if our analysis is only suggestive in this respect, it is not surprising that these broad societal changes have been accompanied by the observed large increase of female-headed households.

Following a generalized trend within Europe, the Italian society is quickly changing its ethnic and religious composition because of immigration. This is introducing yet another source of heterogamy within marriages, as well as different household production arrangements, that may constitute another potential driver of intra-household dynamics. We plan to evaluate these factors in future work.

\section{Appendix. The dataset}

\section{A.1. Sample design and sample weights}

The Bank of Italy Survey of Household Income and Wealth (SHIW) provides plenty of information on representative samples of the Italian population. It is a repeated cross-sectional survey that also contains a panel. The sample design is based on two stages, with municipalities and households as the primary and secondary sampling units respectively. Before the primary units are selected they are stratified by region and population size. Within each stratum, the municipalities in which interviews are to be conducted are selected in order to include all those with a population of more than 40,000 and those with panel households, while the smaller towns are selected on the basis of probability proportional to size. The individual households to be interviewed are then selected randomly.

Given that the sampling design involves unequal stratum sampling fractions, the use of sampling weights is required to obtain unbiased estimates. To this end, all the models presented in this paper are estimated using the sampling weights provided in the Historical Archive of the SHIW (pesofl2), since not only they account for the non-response process, thereby reducing the possible estimation bias, but also they are computed so as to provide estimates of the totals for the reference universe, i.e., the Italian resident population. All weights are given at the household level since all members of the household have the same weight. For more details on the weights see Faiella and Gambacorta (2007). Additional details on the SHIW are available at http://www.bancaditalia.it/statistiche/indcamp/bilfait.

Table A1

Description of variables.

\begin{tabular}{ll}
\hline Variable & Description \\
\hline $\begin{array}{l}\text { SHIW data } \\
\text { Female head }\end{array}$ & $\begin{array}{c}\text { Source: http://www.bancaditalia.it/statistiche/indcamp/bilfait } \\
\text { Binary variable assuming value } 1 \text { if the wife is responsible for the economic and financial } \\
\text { decisions of the household, } 0 \text { otherwise }\end{array}$ \\
Age differential (wife-husband) & $\begin{array}{l}\text { Variable representing the difference between wife and husband age, ranging between }-57 \text { and } \\
\text { Education differential (wife-husband) }\end{array}$ \\
$\begin{array}{l}\text { Variable representing the difference between wife and husband highest education level, } \\
\text { ranging between }-4 \text { and } 3\end{array}$ \\
$\begin{array}{l}\text { Variable representing the difference between wife and husband individual income, ranging } \\
\text { between }-600 \text { and } 101\end{array}$ \\
$\begin{array}{l}\text { Binary variable assuming value } 1 \text { if within the couple the wife is older than the husband, } 0 \\
\text { otherwise }\end{array}$
\end{tabular}


Table A1 (Continued)

\begin{tabular}{|c|c|}
\hline Variable & Description \\
\hline Wife more educated & $\begin{array}{l}\text { Binary variable assuming value } 1 \text { if within the couple the wife is more educated than the } \\
\text { husband, } 0 \text { otherwise }\end{array}$ \\
\hline Wife earns more & $\begin{array}{l}\text { Binary variable assuming value } 1 \text { if within the couple the wife earns a higher income than the } \\
\text { husband, } 0 \text { otherwise }\end{array}$ \\
\hline Household size & $\begin{array}{l}\text { Number of household components ranging between } 2 \text { and } 12 \text {. In the Bank of Italy Survey on } \\
\text { Household Income and Wealth the household is defined as "a group of cohabiting people who, } \\
\text { regardless for their relationships, satisfy their needs by pooling all or part of their incomes" }\end{array}$ \\
\hline Income & $\begin{array}{l}\text { Continuous variable representing yearly disposable household income at } 1989 \text { constant values } \\
\text { expressed in thousand } €\end{array}$ \\
\hline Wealth & $\begin{array}{l}\text { Continuous variable representing household net wealth at } 1989 \text { constant values expressed in } \\
\text { thousand } €\end{array}$ \\
\hline Only wife works & $\begin{array}{l}\text { Binary variable assuming value } 1 \text { if within the couple the wife works and the husband does } \\
\text { not, } 0 \text { otherwise }\end{array}$ \\
\hline Only husband works & $\begin{array}{l}\text { Binary variable assuming value } 1 \text { if within the couple the husband works and the wife does } \\
\text { not, } 0 \text { otherwise }\end{array}$ \\
\hline None works & $\begin{array}{l}\text { Binary variable assuming value } 1 \text { if within the couple neither the wife nor the husband work, } 0 \\
\text { otherwise }\end{array}$ \\
\hline Simple tasks & $\begin{array}{l}\text { Binary variable assuming value } 1 \text { if the household declares to use banking services only to pay } \\
\text { bills, housing rent and mortgage installments or to have wages credited, } 0 \text { otherwise }\end{array}$ \\
\hline Wife's age, husband's age & $\begin{array}{l}\text { Integer variables representing the age of the wife (ranging between } 16 \text { and } 96 \text { ) and of the } \\
\text { husband (ranging between } 19 \text { and 98) }\end{array}$ \\
\hline Wife's education, husband's education & $\begin{array}{l}\text { Categorical variables representing the highest education level among the following achieved } \\
\text { respectively by the wife and the husband: } 1=\text { no education } 4=\text { college } \\
2=\text { primary school } 5=\text { graduate level } \\
3=\text { secondary school } 6=\text { post-graduate level }\end{array}$ \\
\hline Wife's income, husband's income & $\begin{array}{l}\text { Continuous variables representing the individual yearly incomes of the wife and of the } \\
\text { husband respectively, both expressed at } 1989 \text { constant values in thousand } €\end{array}$ \\
\hline Working wife, working husband & Binary variables assuming value 1 if wife and husband respectively are working, 0 otherwise \\
\hline Employee wife, employee husband & $\begin{array}{l}\text { Binary variables assuming value } 1 \text { if wife and husband respectively are working as an } \\
\text { employee, } 0 \text { otherwise }\end{array}$ \\
\hline Self-employed wife, self-employed husband & $\begin{array}{l}\text { Binary variables assuming value } 1 \text { if wife and husband respectively are working as a } \\
\text { self-employed, } 0 \text { otherwise }\end{array}$ \\
\hline Tenured wife, tenured husband & $\begin{array}{l}\text { Binary variable assuming value } 1 \text { if wife and husband respectively hold a tenured working } \\
\text { position, } 0 \text { otherwise (i.e., if they hold a temporary job) }\end{array}$ \\
\hline Part-time job wife, part-time job husband & $\begin{array}{l}\text { Binary variable assuming value } 1 \text { if wife and husband respectively hold a part-time job, } 0 \\
\text { otherwise }\end{array}$ \\
\hline Housewife & Binary variable assuming value 1 if the wife is housewife, 0 otherwise \\
\hline Retired wife, retired husband & Binary variable assuming value 1 if wife and husband respectively are retired, 0 otherwise \\
\hline Istat data & Source: http://www.istat.it/ \\
\hline Divorce hazard & $\begin{array}{l}\text { Number of divorces over number of marriages at the regional level. Ranging between } 2 \% \text { and } \\
45 \%\end{array}$ \\
\hline Female employment rate & $\begin{array}{l}\text { Female employment rate at the regional level, computed as the ratio of women employed over } \\
\text { total female working-age (15-64) population in the region. Ranging between } 13 \% \text { and } 45 \%\end{array}$ \\
\hline
\end{tabular}

Table A2

Descriptive statistics, 1989 and 2010.

\begin{tabular}{|c|c|c|c|c|c|c|c|c|c|}
\hline \multirow[t]{2}{*}{ Variables } & \multicolumn{4}{|c|}{1989 (6212 Obs.) } & \multicolumn{4}{|c|}{2010 (4867 Obs.) } & \multirow{2}{*}{$\begin{array}{l}\text { Test of } \\
\text { mean } \\
\text { equality }\end{array}$} \\
\hline & Mean & St. dev. & Min & Max & Mean & St. dev. & Min & Max & \\
\hline Female head & 0.016 & 0.125 & 0 & 1 & 0.308 & 0.462 & 0 & 1 & $* * *$ \\
\hline \multicolumn{10}{|c|}{ Household characteristics } \\
\hline Household size & 3.388 & 1.143 & 2 & 9 & 3.119 & 1.070 & 2 & 12 & *** \\
\hline Income & 18.830 & 11.663 & -6.38 & 237.14 & 20.954 & 14.653 & -0.47 & 314.81 & ${ }^{* * *}$ \\
\hline Wealth & 81.785 & 106.395 & -29.95 & 2674.21 & 175.05 & 344.612 & -41.03 & $13,990.64$ & ${ }^{* * *}$ \\
\hline Only wife works & 0.028 & 0.164 & 0 & 1 & 0.057 & 0.232 & 0 & 1 & ${ }^{* * *}$ \\
\hline Only husband works & 0.408 & 0.491 & 0 & 1 & 0.266 & 0.442 & 0 & 1 & ${ }^{* * *}$ \\
\hline None works & 0.274 & 0.446 & 0 & 1 & 0.356 & 0.479 & 0 & 1 & $* * *$ \\
\hline Simple tasks & NA & NA & NA & NA & 0.752 & 0.432 & 0 & 1 & NA \\
\hline \multicolumn{10}{|l|}{ Wife's characteristics } \\
\hline Age & 46.893 & 13.767 & 17 & 87 & 52.267 & 14.247 & 18 & 95 & ${ }^{* * *}$ \\
\hline Income & 3.423 & 4.408 & -5.16 & 38.93 & 5.529 & 6.666 & -3.93 & 114.44 & *** \\
\hline Working & 0.318 & 0.466 & 0 & 1 & 0.377 & 0.485 & 0 & 1 & $* * *$ \\
\hline Employee & 0.239 & 0.426 & 0 & 1 & 0.304 & 0.460 & 0 & 1 & *** \\
\hline
\end{tabular}


Table A2 (Continued)

\begin{tabular}{|c|c|c|c|c|c|c|c|c|c|}
\hline \multirow[t]{2}{*}{ Variables } & \multicolumn{4}{|c|}{1989 (6212 Obs.) } & \multicolumn{4}{|c|}{2010 (4867 Obs.) } & \multirow{2}{*}{$\begin{array}{l}\text { Test of } \\
\text { mean } \\
\text { equality }\end{array}$} \\
\hline & Mean & St. dev. & Min & Max & Mean & St. dev. & Min & Max & \\
\hline Self-employed & 0.080 & 0.271 & 0 & 1 & 0.073 & 0.260 & 0 & 1 & \\
\hline Tenured & NA & NA & NA & NA & 0.255 & 0.436 & 0 & 1 & NA \\
\hline Part-time & NA & NA & NA & NA & 0.088 & 0.283 & 0 & 1 & NA \\
\hline Housewife & 0.480 & 0.500 & 0 & 1 & 0.369 & 0.483 & 0 & 1 & $* * *$ \\
\hline Retired & 0.184 & 0.388 & 0 & 1 & 0.211 & 0.408 & 0 & 1 & $* * *$ \\
\hline \multicolumn{10}{|l|}{ Husband's characteristics } \\
\hline Age & 50.586 & 14.029 & 19 & 95 & 55.821 & 14.319 & 20 & 98 & $* * *$ \\
\hline Education & 2.896 & 1.061 & 1 & 6 & 3.265 & 0.986 & 1 & 6 & $* * *$ \\
\hline Income & 13.139 & 9.089 & -11.88 & 229.39 & 13.965 & 11.402 & -1.027 & 307.10 & $* * *$ \\
\hline Working & 0.698 & 0.459 & 0 & 1 & 0.586 & 0.492 & 0 & 1 & $* * *$ \\
\hline Employee & 0.478 & 0.500 & 0 & 1 & 0.414 & 0.493 & 0 & 1 & $* * *$ \\
\hline Self-employed & 0.220 & 0.414 & 0 & 1 & 0.173 & 0.378 & 0 & 1 & $* * *$ \\
\hline Part-time & NA & NA & NA & NA & 0.017 & 0.128 & 0 & 1 & NA \\
\hline Retired & 0.287 & 0.453 & 0 & 1 & 0.374 & 0.484 & 0 & 1 & $* * *$ \\
\hline \multicolumn{10}{|l|}{ Within-couples differentials } \\
\hline Age differential (w-h) & -3.694 & 4.239 & -30 & 48 & -3.554 & 3.992 & -35 & 18 & * \\
\hline Education differential $(\mathrm{w}-\mathrm{h})$ & -0.126 & 0.732 & -4 & 3 & -0.046 & 0.766 & -3 & 3 & *** \\
\hline Income differential $(\mathrm{w}-\mathrm{h})$ & -9.716 & 9.561 & -221.65 & 38.93 & -8.436 & 12.317 & -299.38 & 100.91 & *** \\
\hline \multicolumn{10}{|c|}{ Dummies for within-couples differences } \\
\hline Wife older & 0.010 & 0.30 & 0 & 1 & 0.113 & 0.316 & 0 & 1 & ** \\
\hline Wife more educated & 0.141 & 0.348 & 0 & 1 & 0.197 & 0.398 & 0 & 1 & *** \\
\hline Wife earns more & 0.050 & 0.219 & 0 & 1 & 0.153 & 0.360 & 0 & 1 & *** \\
\hline \multicolumn{10}{|l|}{ Background variables } \\
\hline Divorce hazard & 0.098 & 0.049 & 0.02 & 0.20 & 0.276 & 0.106 & 0.07 & 0.45 & $* * *$ \\
\hline Female employment rate & 0.240 & 0.062 & 0.13 & 0.33 & 0.351 & 0.083 & 0.20 & 0.45 & $* * *$ \\
\hline
\end{tabular}

Note: Statistics computed using sampling weights (pesofl2). Last column reports the significance of the test of equality between the means.

* Significant at $10 \%$

*** Significant at $5 \%$.

**** Significant at $1 \%$.

\section{References}

Alesina, A., Giuliano, P., 2010. The power of the family. Journal of Economic Growth 15, 93-125.

Amuedo-Dorantes, C., Bonke, J., Grossbard, S., 2010. Income pooling and household division of labor: evidence from Danish couples, IZA Discussion Paper No. 5418.

Apps, P.F., Rees, R., 1988. Taxation and the household. Journal of Public Economics 35, 355-369.

Barber, B.M., Odean, T., 2001. Boys will be boys: gender, overconfidence and common stock investments. Quarterly Journal of Economics 116, 261-289.

Becker, G.S., 1973. A theory of marriage: part 1. Journal of Political Economy 81, 813-846.

Becker, G.S., 1965. A theory of the allocation of time. Economic Journal 75, 493-517.

Bertocchi, G., Brunetti, M., Torricelli, C., 2011. Marriage and other risky assets: a portfolio approach. Journal of Banking and Finance 35, $2902-2915$.

Browning, M., Chiappori, P.-A., Weiss, Y., 2007. Family Economics. Cambridge University Press, Cambridge.

Chiappori, P.-A., 1988. Nash-bargained household decisions. International Economic Review 32, 791-796.

Croson, R., Gneezy, U., 2009. Gender differences in preferences. Journal of Economic Literature 47, 448-474.

Del Boca, D., Pasqua, S., 2003. Employment patterns of husbands and wives and family income distribution in Italy (1977-98). Review of Income and Wealth 49, 221-245.

Dobbelsteen, S., Kooreman, P., 1997. Financial management, bargaining and efficiency within the household: an empirical analysis. De Economist 145, 345-366.

Dohmen, T., Falk, A., Huffman, D., Sunde, U., Schupp, J., Wagner, G.G., 2011. Individual risk attitudes: measurement, determinants, and behavioral consequences. Journal of the European Economic Association 9, 522-550.

Edlund, L., Pande, R., 2002. Why have women become more left-wing? The political gender gap and the decline in marriage. Quarterly Journal of Economics 117, 917-961.

Elder, H.W., Rudolph, P.M., 2003. Who makes the financial decisions in the households of older Americans? Financial Services Review 12, $293-308$.

Faiella, I., Gambacorta, R., Bank of Italy Temi di Discussione No. 636 2007. The weighting process in the SHIW.

Fernandez, R., Fogli, A., 2009. Culture: an empirical investigation of beliefs work and fertility. American Economic Journal: Macroeconomics 1, 146-177.

Fernandez, R., Guner, N., Knowles, J., 2005. Love and money: a theoretical and empirical analysis of household sorting and inequality. Quarterly Journal of Economics 120, 273-344.

Friedberg, L., Webb, A., 2006. Determinants and consequences of bargaining power in households. Mimeo. University of Virginia.

Grossbard-Shechtman, S.A., Neuman, S., 1988. Women's labor supply and marital choice. Journal of Political Economy 96, $1294-1302$.

Guiso, L., Jappelli, T., 2002. Household portfolios in Italy. In: Guiso, L., Haliassos, M., Jappelli, T. (Eds.), Household Portfolios. MIT Press, Cambridge.

Halko, M.-L., Kaustia, M., Alanko, E., 2012. The gender effect in risky asset holdings. Journal of Economic Behavior \& Organization 83, 66-81.

Heaton, T.B., 2002. Factors contributing to increasing marital stability in the United States. Journal of Family Issues 23, $392-409$.

Iyigun, M., Walsh, R.P., 2007. Building the family nest: pre-marital investments, marriage markets, and spousal allocations. Review of Economic Studies 74, 507-535.

Jianakoplos, N.A., Bernasek, A., 1998. Are women more risk averse? Economic Inquiry 36, 620-630.

Kalmijn, M., 1991. Shifting boundaries: trends in religious and educational homogamy. American Sociological Review 56, 786-800. 
Lam, D., 1988. Marriage markets and assortative mating with household public goods: theoretical results and empirical implications. Journal of Human Resources 23, 462-487.

Lewis, S.K., Oppenheimer, V.K., 2000. Educational assortative mating across marriage markets: non-Hispanic whites in the United States. Demography 37, 29-40.

Li, L., Wu, X., 2010. Gender of children, bargaining power, and intrahousehold resource allocation in China. Journal of Human Resources 46, 295-316.

Lott, J.R., Kenny, L.W., 1999. Did women's suffrage change the size and scope of government? Journal of Political Economy 107, 1163-1198.

Lührmann, M., Maurer, J., 2007. Who wears the trousers? A semiparametric analysis of decision power in couples, CeMMAP Working Paper No. CWP25/07.

Lundberg, S.J., Startz, R., Stillman, S., 2003. The retirement-consumption puzzle: a marital bargaining approach. Journal of Public Economics 87, 1199-1218.

Lundberg, S.J., Ward-Batts, J., 2000. Saving for retirement: household bargaining and household net worth, Michigan Retirement Research Center Working Paper 2000-004

Lusardi, A., Mitchell, O.S., 2008. Planning and financial literacy: how do women fare? American Economic Review 98, 413-417.

Mare, R.D., 1991. Five decades of educational assortative mating. American Journal of Sociology 56, 15-32.

McElroy, M.B., Horney, M.J., 1981. Nash bargained household decisions: toward a generalization of the theory of demand. International Economic Review 22, 333-349.

Pericoli, F., Ventura, L., 2012. Family dissolution and precautionary savings: an empirical analysis. Review of Economics of the Household 10, 573-595.

Sundén, A.E., Surette, B.J., 1998. Gender differences in the allocation of assets in retirement savings plans. American Economic Review 88, 207-211.

Teachman, J.D., 2002. Stability across cohorts in divorce risk factors. Demography 39, 331-351.

Thomas, D., 1994. Like father, like son; like mother, like daughter: parental resources and child height. Journal of Human Resources $29,950-988$.

Woolley, F., 2003. Control over money in marriage. In: Grossbard-Shechtman, S.A. (Ed.), Marriage and the Economy: Theory and Evidence from Advanced Industrial Societies. Cambridge University Press, New York.

Zissimopoulos, J., Karney, B., Rauer, A., 2013. Marriage and economic well-being at older ages. Review of Economics of the Household (forthcoming). 